\title{
Methane exchange in a poorly-drained black spruce forest over permafrost observed using the eddy covariance technique
}

\author{
Hiroki Iwata $^{\mathrm{a}, \mathrm{b}, \mathrm{c}, *}$, Yoshinobu Harazono ${ }^{\mathrm{b}, \mathrm{d}}$, Masahito Ueyama $^{\mathrm{d}}$, Ayaka \\ Sakabe $^{\mathrm{a}}$, Hirohiko Nagano ${ }^{\mathrm{b}}$, Yoshiko Kosugi ${ }^{\mathrm{a}}$, Kenshi Takahashi ${ }^{\mathrm{e}}$, Yongwon \\ $\mathrm{Kim}^{\mathrm{b}}$ \\ ${ }^{a}$ Graduate School of Agriculture, Kyoto University, Kyoto, Kyoto, Japan. \\ ${ }^{b}$ International Arctic Research Center, University of Alaska Fairbanks, Fairbanks, \\ Alaska, USA. \\ ${ }^{c}$ Department of Environmental Science, Faculty of Science, Shinshu University, \\ Matsumoto, Nagano, Japan. \\ ${ }^{d}$ Graduate School of Life and Environmental Sciences, Osaka Prefecture University, \\ Sakai, Osaka, Japan. \\ ${ }^{e}$ Research Institute of Sustainable Humanosphere, Kyoto University, Uji, Kyoto, Japan.
}

\section{Abstract}

Ecosystem-scale methane $\left(\mathrm{CH}_{4}\right)$ exchange was observed in a poorly-drained black spruce forest over permafrost in interior Alaska during the snow-free seasons of 2011-2013, using the eddy covariance technique. The magnitude of average $\mathrm{CH}_{4}$ exchange differed depending on wind direction, reflecting spatial variation in soil moisture condition around the observation tower, due to elevation change within the small catchment. In the drier upper position, the seasonal variation in $\mathrm{CH}_{4}$ emission was explained by the variation in soil water content only. In the wetter bottom, however, in addition to soil temperature and soil water content, seasonal thaw depth of frozen soil was also an important variable explaining the seasonal variation in $\mathrm{CH}_{4}$ exchange for this ecosystem. Total snow-free season (day of year 134-280) $\mathrm{CH}_{4}$ exchanges were $12.0 \pm 1.0,19.6 \pm 3.0$, and $36.6 \pm 4.4 \mathrm{mmol} \mathrm{m}^{-2}$ season $^{-1}$ for

*Corresponding author.

Hiroki Iwata 
the drier upper position, moderately wet area, and wetter bottom of the catchment, respectively. Observed total season $\mathrm{CH}_{4}$ emission was nearly one order smaller than those reported in other northern wetlands, due probably to the relatively low ground water level and low soil temperature. The interannual variation of total snow-free season $\mathrm{CH}_{4}$ emission in the wetter bottom of the catchment was influenced by the amount of rainfall and thaw depth. On the other hand, in the drier upper position the amount of rainfall did not strongly affect the total season $\mathrm{CH}_{4}$ emission. Different responses of $\mathrm{CH}_{4}$ exchange to seasonal change in environmental conditions, depending on the position of a small catchment, should be considered when estimating the spatial variation in $\mathrm{CH}_{4}$ exchange accurately in ecosystems over permafrost. Keywords: Boreal forest, $\mathrm{CH}_{4}$ flux, Path analysis, Spatial variability, Thaw depth

\section{Introduction}

Methane $\left(\mathrm{CH}_{4}\right)$ is an important greenhouse gas, contributing about $20 \%$ to the total direct radiative forcing from long-lived greenhouse gases since pre-industrial times (Forster et al., 2007). Clarifying the spatial and temporal variations of $\mathrm{CH}_{4}$ exchange is thus of urgent importance for understanding variations in atmospheric $\mathrm{CH}_{4}$ concentration and its influence toward climate changes.

Wetlands are identified as a major natural source of $\mathrm{CH}_{4}$ (Matthews and Fung, 1987; Bousquet et al., 2006; Schlesinger and Bernhardt, 2013). Many studies were conducted to clarify the characteristics of $\mathrm{CH}_{4}$ emission from wetlands (e.g., Sebacher et al., 1986; Moore and Knowles, 1989; Whalen and 
Reeburgh, 1990; Morrissey and Livingston, 1992; Bartlett and Harriss, 1993; Harazono et al., 2006; Mastepanov et al., 2008; Olefeldt et al., 2013; Turetsky et al., 2014). Efforts have been made to clarify ecosystem-scale $\mathrm{CH}_{4}$ emission from wetlands using the eddy covariance technique (e.g., Fan et al., 1992; Verma et al., 1992; Friborg et al., 1997; Hargreaves et al., 2001; Sachs et al., 2008; Zona et al., 2009; McDermitt et al., 2011; Pypker et al., 2013; Euskirchen et al., 2014), and to develop $\mathrm{CH}_{4}$ exchange components in ecosystem models (e.g., Zhuang et al., 2004; Riley et al., 2011; Ringeval et al., 2011; Ito and Inatomi, 2012). Despite these efforts, a recent review by Kirschke et al. (2013) has suggested that $\mathrm{CH}_{4}$ emissions from natural wetlands estimated using ecosystem models were overestimated compared to results from inversion models. A recent wetland model inter-comparison (Melton et al., 2013) also showed large variations in $\mathrm{CH}_{4}$ emissions between ecosystem models, suggesting the need for improving the parameters and structures of ecosystem models. Discrepancy between estimates clearly suggests the need for more efforts to clarify the spatial and temporal variation in ecosystem-scale $\mathrm{CH}_{4}$ exchange for various wetland types, and for model validations based on ecosystem-scale $\mathrm{CH}_{4}$ exchange data.

In a boreal forest region, especially with lowlands and north-facing slopes, permafrost is a characteristic soil condition. Ice-rich permafrost impedes infiltration, and soils tend to be wet or saturated (Hinzman et al., 2006). Thus, quite a large portion of boreal forest can be classified as wetland forest. For example, in boreal Alaska, roughly $40-60 \%$ of the landscape is poorly drained due to the presence of permafrost and characterized by shallow water table conditions (Harden et al., 2003; Myers-Smith et al., 2007). A number 
of studies (e.g., Crill et al., 1988; Whalen and Reeburgh, 1988; Moore et al., 1990; Bartlett et al., 1992; Bubier et al., 1993; Dise, 1993; Moosavi et al., 1996; Bellisario et al., 1999; Wickland et al., 2006; Turetsky et al., 2008; Ullah et al., 2009; Matson et al., 2009) have conducted chamber observations of $\mathrm{CH}_{4}$ exchange in the boreal region in Alaska and Canada, and the seasonal variations in $\mathrm{CH}_{4}$ exchange and its dependence on environmental variables such as soil temperature, soil moisture, and ground water table depth were examined. These studies indicated that different environmental variables appeared to affect $\mathrm{CH}_{4}$ exchange at different temporal and spatial scales, and general and quantitative relationships between environmental variables and $\mathrm{CH}_{4}$ exchange have not yet been found (Olefeldt et al., 2013).

One of the difficulties in studying $\mathrm{CH}_{4}$ exchange is its heterogeneous source/sink distributions with respect to both space and time, making it difficult to cover using chamber observations (Turetsky et al., 2014). Although the chamber technique is useful for examining the influence of environmental conditions on $\mathrm{CH}_{4}$ exchange at the local scale, heterogeneous source/sink distributions have hindered the accurate quantification of $\mathrm{CH}_{4}$ exchange at the ecosystem scale. Poorly-drained boreal forests typically show a large spatial variability in soil moisture from the meter scale of tussock-hollow microtopography to the few hundred-meter scale, due to elevation changes within small catchments. Eddy covariance observation can provide such ecosystem-scale $\mathrm{CH}_{4}$ exchange data, covering a spatial area on a tens- to hundreds-square-kilometer order (Baldocchi et al., 2001). The method is thus useful for quantifications of $\mathrm{CH}_{4}$ exchange and validations of ecosystem models, especially in a boreal region. In addition, eddy covariance observa- 
tion can obtain almost continuous data without disturbing the measurement environment, which may provide detailed insight into a temporal variation in $\mathrm{CH}_{4}$ exchange. This insight will help to obtain more general and quantitative relationship between environmental variables and $\mathrm{CH}_{4}$ exchange. Eddy covariance observations of $\mathrm{CH}_{4}$ exchange in poorly-drained boreal forests, however, has been seldom reported in the literature.

We applied the eddy covariance technique here to observe ecosystem-scale $\mathrm{CH}_{4}$ exchange in a poorly-drained black spruce forest over permafrost in interior Alaska for three snow-free seasons. Black spruce is the dominant species in the Interior, and tends to grow in poorly-drained lowland over permafrost. Our objectives here are 1) to clarify the variations in ecosystem-scale $\mathrm{CH}_{4}$ exchange from diurnal to interannual time scale, 2) to identify the influence of environmental conditions on ecosystem-scale $\mathrm{CH}_{4}$ exchange, and 3) to quantify the total $\mathrm{CH}_{4}$ exchange during snow-free period in this poorly-drained black spruce forest using eddy covariance flux data. To our knowledge, very few studies have reported on an interannual variation of ecosystem-scale $\mathrm{CH}_{4}$ exchange in boreal and arctic region. This study presents new information regarding how ecosystem-scale $\mathrm{CH}_{4}$ exchange during snow-free period responds to seasonal and interannual variations in environmental conditions in a boreal forest using observations of three snow-free seasons.

\section{Observations and Data Analyses}

\subsection{Study Site}

Data were obtained in a poorly-drained black spruce (Picea mariana) forest $\left(64^{\circ} 52^{\prime} \mathrm{N}, 147^{\circ} 51^{\prime} \mathrm{W}, 159 \mathrm{~m}\right.$ a.s.l. $)$, standing on ice-rich permafrost, in 
Fairbanks, Alaska, USA (Ueyama et al., 2006, 2009, 2014; Iwata et al., 2010). Mean tree age is approximately 90 years (Ueyama et al., 2015), and tree height typically ranges from 1 to $5 \mathrm{~m}$, though there are sparsely distributed taller trees of more than $6 \mathrm{~m}$. Tree density is 4500 trees ha $^{-1}$; however, due to the narrow canopy architecture of black spruce, the forest canopy is relatively open. The forest floor has a pronounced tussock-hollow microtopography, and standing water is seen in the hollows when ground water level is high. The understory is dominated by low evergreen shrubs (Ledum groenlandicum, Vaccinium vitis-idaea), deciduous shrubs (Vaccinium uliginosum, Rubus chamaemorus, Betula glandulosa), and sedges (Carex species). The ground is almost completely covered with mosses (Sphagnum and feather mosses). Leaf area index (LAI) of black spruce and understory vegetation, measured with a plant canopy analyzer (LAI-2000, Li-Cor, USA), varied from $0.2 \mathrm{~m}^{2} \mathrm{~m}^{-2}$ during snow season to $1.9 \mathrm{~m}^{2} \mathrm{~m}^{-2}$ during mid-summer. Soil is silt-loam overlain by an organic layer of $25-45 \mathrm{~cm}$ (Heijmans et al., 2004), and is poorly drained due to the presence of ice-rich permafrost. The $\mathrm{pH}$ of ground water above the frozen soil layer was 5-6. Active layer depth was 40-50 cm (Iwata et al., 2012).

The observation tower was located near the bottom of a gentle northwest-facing slope (of approximately one degree; Fig. 1) within a small catchment. Northward is the bottom of the small catchment, which is flat and extends approximately $200 \mathrm{~m}$ from the tower. The terrain gains elevation again to the further north, at approximately one degree. Snowmelt and rain water flows within the surface soil, following topography and converging to the west of the tower, and then flowing into a lake located $270 \mathrm{~m}$ west of the tower. As a result, 
the western portion tends to be wetter than others. Sphagnum moss is the typical surface cover there. Ground water level was generally below ground, except for a short period just after snowmelt. To the south, on the other hand, ground water was not observed due to higher elevation. The ground in that area is typically covered with feather moss and lichen.

Mean monthly air temperature in Fairbanks between 1971 and 2000 ranged from $-23.2{ }^{\circ} \mathrm{C}$ in January to $16.9^{\circ} \mathrm{C}$ in July, and the mean annual precipitation was $263 \mathrm{~mm} \mathrm{yr}^{-1}$ (Shulski and Wendler, 2007). The observation site was typically free of snow from late April through early October.

\subsection{Observation}

$\mathrm{CH}_{4}$ flux was observed using the closed-path eddy covariance technique during three snow-free seasons (early May through early October), in 20112013. An ultrasonic anemo-thermometer (CSAT3, Campbell Scientific, USA) was attached to a 10-m aluminum tower (UT930, Campbell Scientific, USA) at a height of $6 \mathrm{~m}$ above ground. Sample air was drawn from the same height as the anemo-thermometer, and fed to a closed-path $\mathrm{CH}_{4}$ analyzer (RMT-200 Fast Methane Analyzer or Greenhouse Gas Analyzer, Los Gatos Research Inc., USA) placed in a box on the forest floor. The air inlet was placed at a distance of $0.4 \mathrm{~m}$ from the measurement path of the anemo-thermometer, and polyethylene tubing with $9.5 \mathrm{~mm}$ inner diameter was used for sampling. An external pump was placed at the end of the flow line to draw sample air. Two buffer tanks with $1.3 \times 10^{-3} \mathrm{~m}^{3}$ volume were inserted between the $\mathrm{CH}_{4}$ analyzer and the external pump to reduce pressure fluctuation in the sample air. Fluctuation in water vapor concentration for the sampled air was suppressed using a Nafion dryer (PD-200T-48, Perma Pure, Inc., USA). All 
data were recorded at $10 \mathrm{~Hz}$ using a datalogger (CR3000, Campbell Scientific, USA). During the observation period of three years, the observation system was gradually modified, aiming to improve the flux accuracy. The detailed observation system and its modifications are shown in Table 1. Sampling air flow rate was increased by changing the external pump and modifying the flow line. The resultant refreshing time of measurement cell and the Reynolds number of air flow in the sampling tube was, respectively, 2.4s and 1490 for 2011, $1.9 \mathrm{~s}$ and 1940 for 2012, and $0.8 \mathrm{~s}$ and 4620 for 2013.

Relevant micrometeorological observations were also conducted at the tower, including air temperature and relative humidity (HMP45AC or HMP155, Väisälä, Finland) at 2 m, solar radiation (CMP3 or CNR4, Kipp \& Zonen, The Netherlands) at $6 \mathrm{~m}$, and atmospheric pressure (PTB101B, Väisälä, Finland) at $1 \mathrm{~m}$. Within 20-meter distance from the tower, rainfall (TR-525M-R3, Texas Electronics, USA) at $1 \mathrm{~m}$, volumetric soil water content (CS616, Campbell Scientific, USA) for mean values at $0-0.1,0.1-0.2$, and $0.2-0.3 \mathrm{~m}$ depth, soil temperature (thermocouple) at 0.1 and $0.2 \mathrm{~m}$ depths at one location, ground water level (CS445 and CS450, Campbell Scientific, USA) at two locations were all measured. All data were scanned every ten seconds, with half-hourly mean values stored in dataloggers (CR10X and CR23X, Campbell Scientific, USA). Thaw depth was measured manually by inserting a metal rod into the soil approximately once a week. This measurement was conducted with five measurements at each of ten plots. 


\subsection{Data Processing}

\subsubsection{Flux Calculation and Corrections}

Covariances of vertical wind velocity $\left(\mathrm{m} \mathrm{s}^{-1}\right), w$, and $\mathrm{CH}_{4}$ density $\left(\mu \mathrm{mol} \mathrm{m}{ }^{-3}\right)$, $m$, were calculated for half-hourly intervals from the raw $10 \mathrm{~Hz}$ data. Prior to covariance calculation, removal of spike noises (Vickers and Mahrt, 1997), coordinate rotation of wind velocities (double rotation), and synchronization of $\mathrm{CH}_{4}$ density data to wind velocity (Moncrieff et al., 1997) were performed. The median delay time derived from a certain time period (typically, one month) was applied for the synchronization of the whole period. Dependence of delay time on relative humidity (Ibrom et al., 2007) was not observed. In addition, a low-pass filter with two-sec running mean was applied to $\mathrm{CH}_{4}$ density data, to suppress high-frequency instrumental noise, which facilitated the determination of transfer functions described below.

The high-frequency loss of $\mathrm{CH}_{4}$ flux was corrected with an empirical transfer function approach. Transfer functions were determined against cospectra of $w$ and $T_{\mathrm{sv}}$. Figure 2 indicates the cospectral ratios of $\mathrm{CH}_{4}$ flux to sensible heat flux. Although the scatter was large, median values follow a smooth decline with increasing frequency. The transfer function was determined by fitting an equation, $y=1 /\left(1+a x^{b}\right)$ where $a$ and $b$ are parameters, to median values. Parameters were changed every time the eddy covariance system was modified. These transfer functions were combined with an empirical cospectral model, which depends on wind speed and atmospheric stability, to estimate the magnitude of high-frequency loss. More details can be found in Iwata et al. (2014). The cut-off frequency of transfer function was $0.22,0.22$, and $0.08 \mathrm{~Hz}$ for May/2011-June/17/2012, June/17/2012- 
September/2012, and 2013, respectively. The mean correction coefficients and its standard deviations for each period above were $1.5 \pm 0.3,1.3 \pm 0.2$, and $1.9 \pm 0.6$, respectively. Unfortunately, the faster flow rate in 2013 decreased the signal-to-noise ratio, probably resulted in the lower cut-off frequency and the larger correction coefficients.

$\mathrm{CH}_{4}$ exchange was evaluated as the sum of turbulent flux and storage within the atmospheric column below observation height. Storage was estimated from changes of $\mathrm{CH}_{4}$ density over a half-hourly period at the height of the eddy covariance observation.

\subsubsection{Data Selection Criteria and Gap-Filling}

Data used in the analysis were selected from visual inspection of raw 10-Hz data, data quality criteria, footprint analysis, and $u_{*}$ thresholding. First, all $10-\mathrm{Hz}$ data were checked visually for malfunction of instruments. Next, spikes in the raw data were removed using a method of Vickers and Mahrt (1997). Data with abundant spikes, large discontinuities, and strong non-stationarity were discarded (Vickers and Mahrt, 1997; Mahrt, 1998). The fetch contributing $80 \%$ of observed flux was calculated using a footprint model by Kormann and Meixner (2001), and data were selected so that the $80 \%$ fetch did not overlap the non-black spruce area. Then, data with $u_{*}<0.10 \mathrm{~m} \mathrm{~s}^{-1}$ were rejected, for insufficient turbulence conditions (e.g., Rinne et al., 2007; Zona et al., 2009; Long et al., 2010). A sensitivity test for threshold value showed that total $\mathrm{CH}_{4}$ exchange over the observation period, calculated from gap-filled data (described below), was clearly underestimated when data with $u_{*}<0.10 \mathrm{~m} \mathrm{~s}^{-1}$ were included in the analysis, and that even increasing the threshold value above $0.10 \mathrm{~m} \mathrm{~s}^{-1}$ did not change the total $\mathrm{CH}_{4}$ 
exchange.

To obtain daily and seasonal total $\mathrm{CH}_{4}$ exchange, data gaps were filled using the multiple imputation technique (Rubin, 1987; Hui et al., 2004; Enders, 2010). This technique generates several data sets by filling gaps with a different estimation for each data set, based on multiple regression and uncertainty of the regression. Twenty data sets were generated and combined to obtain daily total $\mathrm{CH}_{4}$ exchange and its uncertainty due to gap-filling (Enders, 2010). As independent variables, solar radiation, thaw depth, soil temperature at $0.2 \mathrm{~m}$ depth, and volumetric soil water content between 0.1 and $0.2 \mathrm{~m}$ below ground were used. Thaw depth data was linearly interpolated, and a constant value was assigned for a day. Gap-filling was applied to data using a one-month moving window to fill the gaps from a local relationship between $\mathrm{CH}_{4}$ exchange and environmental variables. The multiple imputation was performed with an Amelia II package (Honaker et al., 2013) in the $R$ statistical software. Comparisons of artificially-removed half-hourly data and imputed half-hourly data for certain one-month intervals suggested that the imputed data can, at least, reconstruct the average $\mathrm{CH}_{4}$ exchange over one-month time scale, but individual imputed half-hourly data might have large uncertainty. This was, in part, because clear relationships between $\mathrm{CH}_{4}$ exchange and environmental variables were not found using half-hourly data due to large uncertainties of observed flux for its small flux magnitude (Appendix A). Thus, we focused on averaged $\mathrm{CH}_{4}$ exchange over half months to examine its temporal variations and the influence of environmental conditions on the exchange.

We observed infrequent spike-like $\mathrm{CH}_{4}$ emission, which met the data selec- 
tion criteria above. These spike-like $\mathrm{CH}_{4}$ emission data were excluded when constructing the relationship between $\mathrm{CH}_{4}$ exchange and environmental variables in the gap-filling procedure, but were retained in calculating the final total $\mathrm{CH}_{4}$ exchange as spike-like $\mathrm{CH}_{4}$ emission is possible when ebullition occurs. Data were identified as the spike-like $\mathrm{CH}_{4}$ emissions when half-hourly $\mathrm{CH}_{4}$ exchange exceeded three times the typical uncertainty due to random error from the local median value of $\mathrm{CH}_{4}$ exchange within a two-week moving window.

\subsection{Analysis}

We first examined the spatial variability of $\mathrm{CH}_{4}$ exchange by analyzing its relationship with wind direction and footprint area. This revealed that the magnitude of $\mathrm{CH}_{4}$ exchange was different across the direction sectors, and we thereafter separated $\mathrm{CH}_{4}$ exchange data into groups according to wind direction. However, we also used identical environmental variables in analyzing each group of data, as information regarding spatial variations in environmental variables between areas was not available. We assumed that seasonal variation in environmental variables such as soil temperature and moisture are correlated between areas, and thus variables obtained at a single place are adequate for explaining seasonal variation in $\mathrm{CH}_{4}$ exchange in all areas.

We applied path analysis (Schemske and Horvitz, 1988; Bassow and Bazzaz, 1998) to $\mathrm{CH}_{4}$ exchange data, in order to examine the relative importance of environmental variables controlling $\mathrm{CH}_{4}$ exchange. Path analysis is an extension of multiple regression and is useful when independent variables have a causal or correlated relationship. In path analysis, a hypothesized model 
(i.e., causal connections between variables) is constructed, and path coefficients are calculated by fitting the model to data. A path coefficient is a standardized partial regression coefficient, and represents the magnitude of the direct effect of the independent variable on the dependent variable, with all other independent variables held constant (Schemske and Horvitz, 1988). In this study, the model was constructed to evaluate relative importance of soil temperature, soil water content, and seasonal thaw depth on $\mathrm{CH}_{4}$ exchange. Rather than finding the best model by including other environmental variables, we intended to identify the change in importance of these fundamental variables under different conditions. The adequacy of the model was determined using a goodness-of-fit index. When the goodness-of-fit index was greater than 0.8 , the model was considered adequate. Path analysis was performed with a sem package (Fox, 2006) in the $R$ statistical software.

\section{Results}

\subsection{Environmental Conditions}

Among environmental variables, rainfall and soil water conditions varied distinctly across the three seasons. The 2011 season, defined as day of year (DOY) 120-270, had total rainfall of $195.1 \mathrm{~mm}$ (Table 2), which was $17 \%$ larger than the 1971-2000 mean (Shulski and Wendler, 2007), with rain events occurring more frequently compared to other years. As a result, volumetric soil water content was higher than other years, and ground water level did not decline below $0.35 \mathrm{~m}$ during mid-summer (Fig. 3). Contrarily, the 2013 season had less rainfall, at $146.1 \mathrm{~mm}-13 \%$ less than the 1971-2000 mean. Rainfall was especially low in the early half of the season: no rainfall 
was observed during DOY 200-231. As a result, mean volumetric soil water content at 0.1-0.2 m depth during DOY 200-231 was 0.54, while in the other years, this value was close to 0.90. Subsequently, volumetric soil water content in 2013 increased due to increased rainfall. The 2012 season had total rainfall comparable to 2011, though there was a long period with little rainfall during DOY 207-236. Volumetric soil water content and ground water level for 2012 declined during this period.

As for temperature, spring 2013 was unusually cold, and snow melt was delayed by about a month compared to typical years. As a result, soil thaw also started later, compared to the other two years (Fig. 3). After snow melt, air temperature rose rapidly, reaching $25.5^{\circ} \mathrm{C}$ on DOY 177, and resulting in a larger range for air temperature in 2013 (Table 2). Soil temperature in summer of 2013 was also higher than the other two years.

Maximum thaw depth was largest in 2011 (Table 2). Higher soil water content enhanced thermal conductivity in the soil (Brown, 1963) in 2011, resulting in the largest thaw depth at the end of the season $(0.40 \mathrm{~m})$. In 2013, contrarily, maximum thaw depth was the lowest $(0.33 \mathrm{~m})$. This is due to drier soil and delayed soil thawing.

\subsection{Spatial Variability of Methane Exchange}

Spatial variability in $\mathrm{CH}_{4}$ exchange reflected the expected spatial variation of soil water conditions due to topography around the observation tower (Fig. 4 and Table 3). $\mathrm{CH}_{4}$ emissions tended to be higher in the 240-300 direction (Table 3), where soil was considered to be wetter. To the northwest (300-360), $\mathrm{CH}_{4}$ emission tended to be comparable to western emissions. In comparison, the southern area emitted less $\mathrm{CH}_{4}$, because the area (120-240 
direction) shows higher elevation and relatively dry soil. Ground water above the frozen soil layer was not seen in this area. The northeast (0-120 direction) showed intermediate $\mathrm{CH}_{4}$ emission levels. Footprint analysis showed no relationship between $\mathrm{CH}_{4}$ exchange and footprint area within the wind direction sectors, suggesting the surface heterogeneity within the direction sectors did not influence the variability in $\mathrm{CH}_{4}$ exchange. Hence, we separated data according to wind direction into 0-120, 120-240, and 240-360 directional sectors. Hereafter, sectors of 0-120, 120-240, and 240-360 degree from the tower are referred to as moderately wet, drier, and wetter areas, respectively.

\subsection{Methane Exchange and Environmental Conditions}

$\mathrm{CH}_{4}$ exchange in this ecosystem had indiscernible diurnal variations (Fig. 5). Most diurnal variation was within a $95 \%$ confidence interval for all areas. For May-June, the difference in median values between areas was not obvious, though median values for $\mathrm{CH}_{4}$ exchange tended to be higher for the wetter area. For July-August, $\mathrm{CH}_{4}$ emissions tended to increase in all areas. The increases were larger in the wetter area, and $\mathrm{CH}_{4}$ emission from the wetter area was clearly higher than in the drier area. Although Fig. 5 showed 2012 data only, other years showed similar patterns.

$\mathrm{CH}_{4}$ emission generally increased from May to August, and at the end of the season, $\mathrm{CH}_{4}$ emission showed a decreasing tendency compared to mid-summer (Fig. 6). The magnitude of seasonal variation was largest for the wetter area. In the wetter area, $\mathrm{CH}_{4}$ emission clearly increased from May/June to July/August in 2011 and 2012: average $\mathrm{CH}_{4}$ emission was $1.9 \pm 0.1$ and $1.2 \pm 0.4 \mathrm{nmol} \mathrm{m}^{-2} \mathrm{~s}^{-1}$ in May/June, and $3.6 \pm 0.8$ and $3.3 \pm$ 
$0.1 \mathrm{nmol} \mathrm{m}^{-2} \mathrm{~s}^{-1}$ for July/August of 2011 and 2012, respectively. The gradual increase in $\mathrm{CH}_{4}$ emission until August was observed in 2011 and 2012 with increases in thaw depth, soil temperature, and soil moisture. At the end of season, $\mathrm{CH}_{4}$ emission decreased, suggesting that $\mathrm{CH}_{4}$ emission was likely suppressed by low soil temperature. In 2013, $\mathrm{CH}_{4}$ emission reduced significantly in the latter half of August $\left(1.4 \mathrm{nmol} \mathrm{m}^{-2} \mathrm{~s}^{-1}\right)$, corresponding with the end of the drought period of 2013. Similar but somewhat smaller seasonal variations were also observed in the moderately wet area. In the drier area, seasonal variation was the smallest of all areas.

Linear regression analysis was applied in order to examine the relationship between $\mathrm{CH}_{4}$ exchange and environmental variables, based on half-monthly average data (Table 4). Analysis showed that $\mathrm{CH}_{4}$ exchange was positively correlated with thaw depth and soil water content at $0.1-0.2 \mathrm{~m}$ and $0.2-0.3 \mathrm{~m}$ depths for all areas. These correlations were less strong for drier area data than in other areas. In the wetter and moderately wet areas, soil temperature at $0.2 \mathrm{~m}$ depth and soil water content at $0-0.1 \mathrm{~m}$ depth were also positively correlated with $\mathrm{CH}_{4}$ exchange. No significant correlation was found between soil temperature at $0.1 \mathrm{~m}$ depth and $\mathrm{CH}_{4}$ exchange.

Soil temperature dependence of $\mathrm{CH}_{4}$ emission showed a complicated pattern (Fig. 7). For example, in 2011 the relationship between $\mathrm{CH}_{4}$ emission and soil temperature displayed a hysteresis pattern, with an emission peak observed in the early half of September, when soil temperature had already begun to decline. In addition, $\mathrm{CH}_{4}$ emission in the late season was slightly larger than early-season emission, although soil temperature was similar. In 2012, an emission peak was not obvious, though the pattern was similar to 
2011. The 2013 season showed a rather different pattern: $\mathrm{CH}_{4}$ emission reduced from July to August, due probably to decreased soil moisture content (Fig. 3). As a result, emission was largest when soil temperature was highest, in the first half of July, 2013.

Path analysis effectively revealed that the environmental variables controlling $\mathrm{CH}_{4}$ exchange varied between different areas (Fig. 8). In the drier area, soil water affected $\mathrm{CH}_{4}$ exchange (path coefficient of $0.68, p=0.13$ ), and effects from thaw depth and soil temperature were only marginal. In the wetter area, thaw depth was most important (path coefficient of 0.44 , $p=0.29$ ). The path coefficient for soil temperature on $\mathrm{CH}_{4}$ exchange for the wetter area was $0.17(p=0.20)$, which was greater than in the drier area $(-0.06, p=0.69)$. On the other hand, the path coefficient for soil water content for the wetter area $(0.20, p=0.62)$ was lower than in the drier area. Thus, the relative importance of soil water content was higher in the drier area, while that of thaw depth was higher in the wetter area. In the moderately wet area, the path coefficients of three variables for $\mathrm{CH}_{4}$ exchange took values between those of the drier and wetter areas.

\subsection{Total Snow-Free Season Methane Exchange}

Total snow-free season $\mathrm{CH}_{4}$ emission (Table 5) was also, on average, greatest in the wetter area, followed by the moderately wet area. For the wetter area, total $\mathrm{CH}_{4}$ emission was greatest in $2011\left(45.0 \mathrm{mmol} \mathrm{m}^{-2}\right.$ season $\left.^{-1}\right)$, when deepest thaw depth and highest soil water content were observed. The 2013 season had lowest total $\mathrm{CH}_{4}$ emission $\left(30.3 \mathrm{mmol} \mathrm{m}^{-2}\right.$ season $\left.^{-1}\right)$, while total $\mathrm{CH}_{4}$ emission in the 2012 season $\left(34.6 \mathrm{mmol} \mathrm{m}^{-2}\right.$ season $\left.{ }^{-1}\right)$ was slightly greater than in 2013. In the drier area, total season $\mathrm{CH}_{4}$ emission did not 
vary largely across the three years $\left(12.0 \pm 1.7 \mathrm{mmol} \mathrm{m}^{-2}\right.$ season $\left.^{-1}\right)$.

\section{Discussion}

In general, $\mathrm{CH}_{4}$ exchange responds to environmental conditions such as soil temperature and soil moisture (e.g., Sebacher et al., 1986; Crill et al., 1988; Christensen et al., 1995; von Fischer et al., 2010), as $\mathrm{CH}_{4}$ is produced by methanogens and consumed by methanotrophs, and the activity of these bacteria is influenced by temperature and oxygen availability. In the diurnal cycle, soil temperature can be the main controlling variable, as moisture condition does not change over single days. $\mathrm{CH}_{4}$ exchange in the poorly-drained black spruce forest, however, did not show any obvious diurnal variations (Fig. 5). Similar results have been reported in a boreal fen (Rinne et al., 2007), an Arctic wet tundra (Harazono et al., 2006; Tagesson et al., 2012), and a sub-boreal peatland (Pypker et al., 2013). At our site, the lack of obvious diurnal variation in $\mathrm{CH}_{4}$ exchange may suggest that most $\mathrm{CH}_{4}$ was likely produced in a deeper active layer soil, where diurnal variation in soil temperature was not significant (Moosavi and Crill, 1997). The ground covered by moss showed low thermal conductivity and the typical magnitude of daily soil temperature variation was about $1{ }^{\circ} \mathrm{C}$ at $0.2 \mathrm{~m}$ depth (data not shown), with ground water table below this depth during most of the observation period (Fig. 3). In contrast, $\mathrm{CH}_{4}$ oxidation was also expected to occur in aerobic surface soil, where temperature variation was larger than in deeper soil, and to increase during daytime. A part of this expected increase in $\mathrm{CH}_{4}$ oxidation could be canceled out by an increase of $\mathrm{CH}_{4}$ production during daytime, depending on the strength of both $\mathrm{CH}_{4}$ production and ox- 
idation, and the magnitude of their temperature dependence (Segers, 1998; van Winden et al., 2012).

At the bottom of the small catchment, soil tended to be wetter, with ground water below the soil surface. Here, thaw depth was the most important variable controlling $\mathrm{CH}_{4}$ emission (Fig. 8). Thaw depth is a variable, integrating conditions favorable for $\mathrm{CH}_{4}$ production (Whalen and Reeburgh, 1992). Sturtevant et al. (2012) and Kim (2015) also showed that thaw depth is a key environmental variable in regulating $\mathrm{CH}_{4}$ exchange in Arctic tundra, although their studies showed far stronger sensitivity of $\mathrm{CH}_{4}$ emission to increase in thaw depth when thaw depth was more than $30 \mathrm{~cm}$. Soil thaw likely regulated the vertical extent to which methanogens can be active, thus influencing the base $\mathrm{CH}_{4}$ emission rate. Microbial population could also increase later in the season compared to spring season (Funk et al., 1994; Moosavi et al., 1996; van Hulzen et al., 1999). These factors can explain the higher $\mathrm{CH}_{4}$ emission rate later in the season, though soil temperature was similar (Fig. 7). The relative importance of soil temperature was also higher in the wetter area than the drier area. This may be because soil was wet for most of the observation period in the wetter area, with soil temperature more effective in enhancing methanogen activity than in the drier area (Morrissey and Livingston, 1992; Moosavi et al., 1996; Olefeldt et al., 2013). JackowiczKorczyński et al. (2010) and Parmentier et al. (2011) similarly reported that responses of $\mathrm{CH}_{4}$ emission to environmental variables varied depending on vegetation and surface conditions in a single eddy covariance site.

Permafrost condition may also affect the spatial variability of $\mathrm{CH}_{4}$ exchange. Degradation of permafrost in the northwestern portion has occurred 
under inundated standing water there; on the other hand, permafrost in the southern area is still stable (V. Romanovsky, 2014, personal communication). In this poorly-drained black spruce forest, higher $\mathrm{CH}_{4}$ emission was observed in the northwestern area, where degradation of permafrost had occurred. Further degradation of permafrost may enhance $\mathrm{CH}_{4}$ emission (Olefeldt et al., 2013) in this ecosystem.

Even in the drier area, where no ground water was present above the frozen soil layer, small net $\mathrm{CH}_{4}$ emission was observed in our black spruce forest (Fig. 6 and Table 5). This suggests that $\mathrm{CH}_{4}$ was also produced within an anaerobic microsite in the unsaturated soil (von Fischer and Hedin, 2002; Blankinship et al., 2010). The increase in soil water content likely extended the anaerobic microsite area, resulting in enhanced $\mathrm{CH}_{4}$ emission later in the season (Fig. 6 and 8).

Total snow-free season $\mathrm{CH}_{4}$ emission in this poorly-drained black spruce forest (Table 5) was nearly one order smaller than emissions reported for other northern wetland ecosystems: e.g., $788 \mathrm{mmol} \mathrm{m}^{-2}$ over one year in a boreal fen in southern Finland (Rinne et al., 2007), $633 \mathrm{mmol} \mathrm{m}^{-2}$ over four months in an Arctic tundra in Greenland (Tagesson et al., 2012), 258$515 \mathrm{mmol} \mathrm{m}^{-2}$ over four months in an Arctic wet tundra (Harazono et al., 2006), $311 \mathrm{mmol} \mathrm{m}^{-2}$ over six months in a collapsed scar bog in Alaska (Euskirchen et al., 2014), $200 \mathrm{mmol} \mathrm{m}^{-2}$ over four months in a peatland in southern Canada (Long et al., 2010), and $121 \mathrm{mmol} \mathrm{m}^{-2}$ over three months in an Arctic tundra in northern Siberia (Sachs et al., 2008). The relatively low ground water level (approximately $0.2-0.4 \mathrm{~m}$ below ground; Fig. 3) was attributable to low $\mathrm{CH}_{4}$ emission in this forest. The tundra sites in colder 
climate listed above had both higher ground water levels and $\mathrm{CH}_{4}$ emissions. At landscape scale, spatial variation of $\mathrm{CH}_{4}$ emission was reported to be related to that of ground water level (Sebacher et al., 1986; Olefeldt et al., 2013). The low $\mathrm{CH}_{4}$ emission in this forest also indicates that quite a large fraction of $\mathrm{CH}_{4}$ produced in deeper soil could be consumed in aerobic surface soil and Sphagnum moss layer while transported to the atmosphere by diffusion (Conrad and Rothfuss, 1991; Whalen et al., 1996; Kip et al., 2010). In addition, soil temperature at this site was relatively low underlain by permafrost, thus constraining $\mathrm{CH}_{4}$ emission, compared to wetland sites without permafrost in warmer climates (Turetsky et al., 2014).

So far, few studies have reported the interannual variation in $\mathrm{CH}_{4}$ exchange in a boreal and arctic wetland. Our study showed that the $\mathrm{CH}_{4}$ emission of the wetter area within the forest was the largest in 2011 (Table 5), a year with the largest amount of rainfall and the greatest thaw depth among the three years (Table 2). The combination of large amount of rainfall and deep thaw led to greater vertical extent of anaerobic soil layer, and thus potentially enhanced the $\mathrm{CH}_{4}$ production. Similarly, a few studies (Parmentier et al., 2011; Tagesson et al., 2012; Brown et al., 2014) in the literature reported a higher $\mathrm{CH}_{4}$ emission in a wetter year from a two-year observation. On the other hand, our study showed that the interannual variation in $\mathrm{CH}_{4}$ emission in the drier area was insignificant regardless of the amount of rainfall. The lower amount of rainfall in 2013 resulted in lower soil water content in the soil surface layer (Fig. 3). However, the deeper soil layer where $\mathrm{CH}_{4}$ was presumably produced was relatively unaffected due to water input from soil thawing, especially later in the season. Thus, the interannual variation 
in $\mathrm{CH}_{4}$ emission in the drier area was not strongly affected by the amount of rainfall.

Finally, we discuss the contribution of $\mathrm{CH}_{4}$ emission to the greenhouse gas budget in this black spruce forest. In 2011, the same forest emitted $\mathrm{CO}_{2}$ of $5.5 \mathrm{~mol} \mathrm{~m}^{-2} \mathrm{y}^{-1}$ (Ueyama et al., 2014). Whereas, the moderately wet area of the black spruce forest emitted $\mathrm{CH}_{4}$ of $23.2 \mathrm{mmol} \mathrm{m}{ }^{-2}$ in 2011 snow-free season (Table 5). Kim et al. (2007) reported from an observation conducted in 2005-06 winter in the same forest that the $\mathrm{CH}_{4}$ emission was $9.4 \mathrm{mmol} \mathrm{m}{ }^{-2}$ during winter time. Assuming the similar winter $\mathrm{CH}_{4}$ emission in 2011, we estimated that the annual $\mathrm{CH}_{4}$ emission in 2011 could be $32.6 \mathrm{mmol} \mathrm{m}^{-2}$, which was equivalent to $\mathrm{CO}_{2}$ emission of $0.3 \mathrm{~mol} \mathrm{~m}^{-2}$ with the global warming potential of $\mathrm{CH}_{4}$ as 9.1 for a molar basis (Forster et al., 2007). Thus, the contribution of $\mathrm{CH}_{4}$ emission to the greenhouse gas budget was $5 \%$ in this forest in 2011. The $\mathrm{CH}_{4}$ emission in this black spruce forest could not be overlooked when considering the greenhouse gas budget due to its stronger global warming potential.

\section{Conclusions}

Here we examined seasonal and interannual variations in ecosystem-scale $\mathrm{CH}_{4}$ exchange at a poorly-drained black spruce forest over permafrost, representing one of the typical ecosystems of interior Alaska and boreal Canada.

The magnitude of $\mathrm{CH}_{4}$ emission and its dependence on environmental variables varied, depending on the position within a small catchment. $\mathrm{CH}_{4}$ emission was greater at the wetter bottom of the small catchment than at a drier upper position. At the drier upper position, soil water content affected the 
seasonal variation in $\mathrm{CH}_{4}$ emission. At the wetter bottom, in addition to soil temperature and soil water content, seasonal thaw depth of frozen soil was also an important variable explaining the seasonal variation in $\mathrm{CH}_{4}$ exchange. These different responses to changes in environmental conditions within the ecosystem should be considered when estimating the spatial variation in $\mathrm{CH}_{4}$ exchange in ecosystems over permafrost. The interannual variation of total snow-free season $\mathrm{CH}_{4}$ emission in the wetter bottom of the catchment (30.3$45.0 \mathrm{mmol} \mathrm{m}^{-2}$ season $^{-1}$ ) was influenced by the amount of rainfall and thaw depth. On the other hand, in the drier upper position the amount of rainfall did not strongly affect the total season $\mathrm{CH}_{4}$ emission, because the deeper soil layer where $\mathrm{CH}_{4}$ was presumably produced was kept wet from soil thawing even in a year with low rainfall. Total season $\mathrm{CH}_{4}$ emission was nearly one order smaller than those reported in other northern wetland ecosystems, likely due to the relatively low ground water level and soil temperature. However, degradation of the ice-rich permafrost, expected in future warmer environment, may enhance $\mathrm{CH}_{4}$ emission in boreal forests with permafrost. $\mathrm{CH}_{4}$ exchange components in ecosystem models have not sufficiently been validated for various wetland types, and it has not been assured whether the models can reproduce both spatial and temporal variations in $\mathrm{CH}_{4}$ exchange. Further efforts are needed to improve the ecosystem models using eddy covariance observations for accurate estimates of regional and global $\mathrm{CH}_{4}$ exchange. 


\section{Acknowledgments}

This research was funded through grants to the University of Alaska Fairbanks, International Arctic Research Center from NSF under the Carbon Cycle Program of IARC/NSF, from the Japan Aerospace Exploration Agency (JAXA) under the "Arctic Research Plan Utilizing the IARC-JAXA Information System (IJIS) and Satellite Imagery", and from the Japan Agency for Marine-Earth Science and Technology (JAMSTEC) under the JAMSTECIARC Collaboration Study, and by JSPS KAKENHI Grant Number 23310009 (FY2011-2013) and 23248023 (FY2011-2013). We would like to thank Mr. N. Bauer for proofreading the manuscript, and the editor and two anonymous reviewers for their constructive comments.

\section{Appendix A. Uncertainty Evaluation}

Random errors in $\mathrm{CH}_{4}$ flux due to limited averaging time and the instrumental noise were evaluated using the method from Meyers et al. (1998) and Finkelstein and Sims (2001). To account for the effect of high-frequency loss, calculated random errors were multiplied with the same correction coefficients as fluxes. Random error tended to increase with increasing absolute magnitude of flux (Fig. 9), with typically $30 \%$ of flux for positive values and $80 \%$ of flux for negative values.

The total uncertainty of observed $\mathrm{CH}_{4}$ exchange was estimated by combining uncertainties due to random error and gap-filling, assuming uncertainties are independent and random (Taylor, 1997). Half-hourly uncertainties due to random error were added in quadrature, to obtain uncertainties of 
total $\mathrm{CH}_{4}$ exchange due to random error-i.e.,

$$
U_{\text {total }, \mathrm{RE}}=\sqrt{\sum_{\mathrm{i}=1}^{N} U_{\mathrm{RE}, \mathrm{i}}{ }^{2}}
$$

where $U_{\text {total,RE }}$ is the uncertainty of total exchange due to random error, $U_{\mathrm{RE}, \mathrm{i}}$ is half-hourly uncertainty due to random error, and $N$ is the number of data to be summed. For gap-filled data, the obtained relationships, as shown in Fig. 9, were used to estimate random errors of fluxes. For gap-filled fluxes with an absolute magnitude smaller than $1.25 \mathrm{nmol} \mathrm{m}{ }^{-2} \mathrm{~s}^{-1}$, median value was obtained for this range, and this constant value was assigned as the random error of gap-filled fluxes. Similarly, uncertainties in daily total $\mathrm{CH}_{4}$ exchange due to gap-filling described in the previous section were also added in quadrature, to obtain the uncertainty in total $\mathrm{CH}_{4}$ exchange. Finally, the uncertainty in total $\mathrm{CH}_{4}$ exchange due to both random error and gap-filling was combined by adding them in quadrature.

\section{References}

Baldocchi, D., Falge, E., Gu, L., Olson, R., Hollinger, D., Running, S., Anthoni, P., Bernhofer, C., Davis, K., Evans, R., Fuentes, J., Goldstein, A., Katul, G., Law, B., Lee, X., Malhi, Y., Meyers, T., Munger, W., Oechel, W., Paw U, K. T., Pilegaard, K., Schmid, H. P., Valentini, R., Verma, S., Vesala, T., Wilson, K., Wofsy, S., 2001. FLUXNET: a new tool to study the temporal and spatial variability of ecosystem-scale carbon dioxide, water vapor, and energy flux densities. Bull. Amer. Meteorol. Soc. $82,2415-2434$. 
Bartlett, K. B., Crill, P. M., Sass, R. L., Harriss, R. C., Dise, N. B., 1992. Methane emissions from tundra environments in the Yukon-Kuskokwim Delta, Alaska. J. Geophys. Res. 97, 16645-16660.

Bartlett, K. B., Harriss, R. C., 1993. Review and assessment of methane emissions from wetlands. Chemosphere 26, 261-320.

Bassow, S. L., Bazzaz, F. A., 1998. How environmental conditions affect canopy leaf-level photosynthesis in four deciduous tree species. Ecol. 79, $2660-2675$.

Bellisario, L. M., Bubier, J. L., Moore, T. R., Chanton, J. P., 1999. Controls on $\mathrm{CH}_{4}$ emissions from a northern peatland. Global Biogeochem. Cycles $13,81-91$.

Blankinship, J. C., Brown, J. R., Dijkstra, P., Hungate, B. A., 2010. Effects of interactive global changes on methane uptake in an annual grassland. J. Geophys. Res. Biogeosci. 115, G02008.

Bousquet, P., Ciais, P., Miller, J. B., Dlugokencky, E. J., Hauglustaine, D. A., Prigent, C., Van der Werf, G. R., Peylin, P., Brunke, E.-G., Carouge, C., Langenfelds, R. L., Lathiére, J., Papa, F., Ramonet, M., Schmidt, M., Steele, L. P., Tyler, S. C., White, J., 2006. Contribution of anthropogenic and natural sources to atmospheric methane variability. Nature 443, 439443.

Brown, R. J. E., 1963. Influence of vegetation on permafrost. In: Permafrost International Conference. pp. 20-25. 
Brown, M. G., Humphreys, E. R., Moore, T. R., Roulet, N. T., Lafleur, P. M., 2014. Evidence for a nonmonotonic relationship between ecosystem-scale peatland methane emissions and water table depth. J. Geophys. Res. Biogeosci. 119, 826-835.

Bubier, J. L., Moore, T. R., Roulet, N. T., 1993. Methane emissions from wetlands in the midboreal region of northern Ontario, Canada. Ecology $74,2240-2254$.

Christensen, T. R., Jonasson, S., Callaghan, T. V., Havström, M., 1995. Spatial variation in high-latitude methane flux along a transect across Siberian and European tundra environments. J. Geophys. Res. 100, 21035-21045.

Conrad, R., Rothfuss, E., 1991. Methane oxidation in the soil surface layer of a flooded rice field and the effect of ammonium. Biol. Fertil. Soils 12, $28-32$.

Crill, P. M., Bartlett, K. B., Harriss, R. C., Gorham, E., Verry, E. S., Sebacher, D. I., Madsar, L., Sanner, W., 1988. Methane flux from Minnesota peatlands. Global Biogeochem. Cycles 2, 371-384.

Dise, N. B., 1993. Methane emission from Minnesota peatlands: spatial and seasonal variability. Global Biogeochem. Cycles 7, 123-142.

Enders, C. K., 2010. Applied missing data analysis. The Guilford Press, New York, 377p.

Euskirchen, E. S., Edgar, C. W., Turetsky, M. R., Waldrop, M. P., Harden, J. W., 2014. Differential response of carbon fluxes to climate in three peat- 
land ecosystems that vary in the presence and stability of permafrost. J. Geophys. Res. Biogeosci. doi:10.1002/2014JG002683.

Fan, S. M., Wofsy, S. C., Bakwin, P. S., Jacob, D. J., Anderson, S. M., Kebabian, P. L., McManus, J. B., Kolb, C. E., Fitzjarrald, D. R., 1992. Micrometeorologica measurements of $\mathrm{CH}_{4}$ and $\mathrm{CO}_{2}$ exchange between the atmosphere and subarctic tundra. J. Geophys. Res. 97 (D15), 16627-16643.

Finkelstein, P. L., Sims, P. F., 2001. Sampling error in eddy correlation flux measurements. J. Geophys. Res. Atmos. 106, 3503-3509.

Forster, P., Ramaswamy, V., Artaxo, P., Berntsen, T., Betts, R., Fahey, D., Haywood, J., Lean, J., Lowe, D., Myhre, G., Nganga, J., Prinn, R., Raga, G., Schulz, M., Van Dorland, R., 2007. Changes in atmospheric constituents and in radiative forcing. In: Climate Change 2007: The Physical Science Basis. Cambridge University Press, U. K., pp. 129-234.

Fox, J., 2006. Structural equation modeling with the sem package in R. Structual Equation Modeling 13, 465-486.

Friborg, T., Christensen, T. R., Søgaard, H. ., 1997. Rapid response of greenhouseg as emission to early spring thaw in a subarctic mire as shown by micrometeorological techniques. Geophys. Res. Lett. 24, 3061-3064.

Funk, D. W., Pullman, E. R., Peterson, K. M., Crill, P. M., Billings, W. D., 1994. Influence of water table on carbon dioxide, carbon monoxide, and methane fluxes from taiga bog microcosms. Global Biogeochem. Cycles 8, $271-278$. 
Harazono, Y., Mano, M., Miyata, A., Yoshimoto, M., Zulueta, R. C., Vourlitis, G. L., Kwon, H., Oechel, W. C., 2006. Temporal and spatial differences of methane flux at arctic tundra in Alaska. Mem. Natl. Inst. Polar Res. 59, 79-95.

Harden, J. W., Meier, R., Silapaswan, C., Swanson, D. K., McGuire, A. D., 2003. Soil drainage and its potential for influencing wildfires in Alaska. In: Galloway, J. P. (Ed.), Studies by the U.S. Geological Survey in Alaska, 2001. U.S. Geological Survey Professional Paper 1678. U.S. Geological Survey, pp. 139-144.

Hargreaves, K. J., Fowler, D., Pitcairn, C. E. R., Aurela, M., 2001. Annual methane emission from Finnish mires estimated from eddy covariance campaign measurements. Theor. Appl. Climatol. 70, 203-213.

Heijmans, M. M. P. D., Arp, W. J., Chapin III, F. S., 2004. Carbon dioxide and water vapour exchange from understory species in boreal forest. Agric. For. Meteorol. 123, 135-147.

Hinzman, L. D., Bolton, W. R., Petrone, K. C., Jones, J. B., Adams, P. C., 2006. Watershed hydrology and chemistory in the Alaskan boreal forest. the central role of permafrost. In: Chapin III, F. S., Oswood, M., Van Cleve, K., Viereck, L. A., Verbyla, D. L. (Eds.), Alaska's changing boreal forest. Oxford University Press, Oxford, pp. 269-284.

Honaker, J., King, G., Blackwell, M., 2013. AMELIA II: a program for missing data. 
Hui, D., Wan, S., Su, B., Katul, G., Monson, R., Luo, Y., 2004. Gap-filling missing data in eddy covariance measurements using multiple imputation (MI) for annual estimations. Agric. For. Meteorol. 121, 93-111.

Ibrom, A., Dellwik, E., Flyvbjerg, H., Jensen, N. O., Pilegaard, K., 2007. Strong low-pass filtering effects on water vapour flux measurements with closed-path eddy correlation systems. Agric. For. Meteorol. 147, 140-156.

Ito, A., Inatomi, M., 2012. Use of a process-based model for assessing the methane budgets of global terrestrial ecosystems and evaluation of uncertainty. Biogeosciences 9, 759-773.

Iwata, H., Harazono, Y., Ueyama, M., 2010. Influence of source/sink distributions on flux-gradient relationships in the roughness sublayer over an open forest canopy under unstable conditions. Boundary-Layer Meteorol. $136,391-405$.

Iwata, H., Harazono, Y., Ueyama, M., 2012. The role of permafrost in water exchange of a black spruce forest in Interior Alaska. Agric. For. Meteorol. $161,107-115$.

Iwata, H., Kosugi, Y., Ono, K., Mano, M., Sakabe, A., Miyata, A., Takahashi, K., 2014. Cross-validation of open-path and closed-path eddy-covariance techniques for observing methane fluxes. Boundary-Layer Meteorol. 151, $95-118$

Jackowicz-Korczyński, M., Christensen, T. R., Bäckstrand, K., Crill, P., Friborg, T., Mastepanov, M., Ström, L., 2010. Annual cycle of methane emission from a subarctic peatland. J. Geophys. Res. Biogeosci. 115, G02009. 
Kim, Y., 2015. Effect of thaw depth on fluxes of $\mathrm{CO}_{2}$ and $\mathrm{CH}_{4}$ in manipulated Arctic coastal tundra of Barrow, Alaska. Sci. Total Environ. 505, 385-389.

Kim, Y., Ueyama, M., Nakagawa, F., Tsunogai, U., Harazono, Y., Tanaka, N., 2007. Assessment of winter fluxes of $\mathrm{CO}_{2}$ and $\mathrm{CH}_{4}$ in boreal forest soils of central Alaska estimated by the profile method and the chamber method: a diagnosis of methane emission and implications for the regional carbon budget. Tellus 59B, 223-233.

Kip, N., van Winden, J. F., Pan, Y., Bodrossy, L., Reichart, G.-J., Smolders, A. J. P., Jetten, M. S. M., Damsté, J. S. S., den Camp, H. J. M. O., 2010. Global prevalence of methane oxidation by symbiotic bacteria in peat-moss ecosystems. Nat. Geosci. 3, 617-621.

Kirschke, S., Bousquet, P., Ciais, P., Saunois, M., Canadell, J. G., Dlugokencky, E. J., Bergamaschi, P., Bergmann, D., Blake, D. R., Bruhwiler, L., Cameron-Smith, P., Castaldi, S., Chevallier, F., Feng, L., Fraser, A., Heimann, M., Hodson, E. L., Houweling, S., Josse, B., Fraser, P. J., Krummel, P. B., Lamarque, J.-F., Langenfelds, R. L., Le Quéré, C., Naik, V., O'Doherty, S., Palmer, P. I., Pison, I., Plummer, D., Poulter, B., Prinn, R. G., Rigby, M., Ringeval, B., Santini, M., Schmidt, M., Shindell, D. T., Simpson, I. J., Spahni, R., Steele, L. P., Strode, S. A., Sudo, K., Szopa, S., van der Werf, G. R., Voulgarakis, A., van Weele, M., Weiss, R. F., Williams, J. E., Zeng, G., 2013. Three decades of global methane sources and sinks. Nat. Geosci. 6, 813-823.

Kormann, R., Meixner, F. X., 2001. An analytical footprint model for non-neutral stratification. Boundary-Layer Meteorol. 99, 207-224. 
Long, K. D., Flanagan, L. B., Cai, T., 2010. Diurnal and seasonal variation in methane emissions in a northern Canadian peatland measured by eddy covariance. Global Change Biol. 16, 2420-2435.

Mahrt, L., 1998. Flux sampling errors for aircraft and towers. J. Atmos. Oceanic Technol. 15, 416-429.

Mastepanov, M., Sigsgaard, C., Dlugokencky, E. J., Houweling, S., Ström, L., Tamstorf, M. P., Christensen, T. R., 2008. Large tundra methane burst during onset of freezing. Nature 456, 628-631.

Matson, A., Pennock, D., Bedard-Haughn, A., 2009. Methane and nitrous oxide emissions from mature forest stands in the boreal forest, Saskatchewan, Canada. For. Ecol. Manage. 258, 1073-1083.

Matthews, E., Fung, I., 1987. Methane emission from natural wetlands: global distribution, area, and environmental characteristics of sources. Global Biogeochem. Cycles 1, 61-86.

McDermitt, D., Burba, G., Xu, L., Anderson, T., Komissarov, A., Riensche, B., Schedlbauer, J., Starr, G., Zona, D., Oechel, W., Oberbauer, S., Hastings, S., 2011. A new low-power, open-path instrument for measuring methane flux by eddy covariance. Appl. Phys. B 102, 391-405.

Melton, J. R., Wania, R., Hodson, E. L., Poulter, B., Ringeval, B., Spahni, R., Bohn, T., Avis, C. A., Beerling, D. J., Chen, G., Eliseev, A. V., Denisov, S. N., Hopcroft, P. O., Lettenmaier, D. P., Riley, W. J., Singarayer, J. S., Subin, Z. M., Tian, H., Zürcher, S., Brovkin, V., van Bodegom, P. M., Kleinen, T., Yu, Z. C., Kaplan, J. O., 2013. Present state of 
global wetland extent and wetland methane modelling: conclusions from a model inter-comparison project (WETCHIMP). Biogeosciences 10, 753788.

Meyers, T. P., Finkelstein, P., Clarke, J., Ellestad, T. G., Sims, P. F., 1998. A multilayer model for inferring dry deposition using standard meteorological measurements. J. Geophys. Res. Atmos. 103, 22645-22661.

Moncrieff, J. B., Massheder, J. M., de Bruin, H., Elbers, J., Friborg, T., Heusinkveld, B., Kabat, P., Scott, S., Soegaard, H., Verhoef, A., 1997. A system to measure surface fluxes of momentum, sensible heat, water vapour and carbon dioxide. J. Hydrol. 188-189, 589-611.

Moore, T., Roulet, N., Knowles, R., 1990. Spatial and temporal variations of methane flux from subarctic/northern boreal fens. Global Biogeochem. Cycles 4, 29-46.

Moore, T. R., Knowles, R., 1989. The influence of water table levels on methane and carbon dioxide emissions from peatland soils. Can. J. Soil Sci. 69, 33-38.

Moosavi, S. C., Crill, P. M., 1997. Controls on $\mathrm{CH}_{4}$ and $\mathrm{CO}_{2}$ emissions along two moisture gradients in the Canadian boreal zone. J. Geophys. Res. Atmos. 102, 29261-29277.

Moosavi, S. C., Crill, P. M., Pullman, E. R., Funk, D. W., Peterson, K. M., 1996. Controls on $\mathrm{CH}_{4}$ flux from an Alaskan boreal wetland. Global Biogeochem. Cycles 10, 287-296. 
Morrissey, L. A., Livingston, G. P., 1992. Methane emissions from Alaska arctic tundra: an assessment of local spatial variability. J. Geophys. Res. 97, 16661-16670.

Myers-Smith, I. H., McGuire, A. D., Harden, J. W., Chapin III, F. S., 2007. Influence of disturbance on carbon exchange in a permafrost collapse and adjacent burned forest. J. Geophys. Res. Biogeosci. 112, G04017.

Olefeldt, D., Turetsky, M. R., Crill, P. M., McGuire, A. D., 2013. Environmental and physical controls on northern terrestrial methane emissions across permafrost zones. Global Change Biol. 19, 589-603.

Parmentier, F. J. W., van Huissteden, J., van der Molen, M. K., SchaepmanStrub, G., Karsanaev, S. A., Maximov, T. C., Dolman, A. J., 2011. Spatial and temporal dynamics in eddy covariance observations of methane fluxes at a tundra site in Northeastern Siberia. J. Geophys. Res. Biogeosci. 116, G03016.

Pypker, T. G., Moore, P. A., Waddington, J. M., Hribljan, J. A., Chimner, R. C., 2013. Shifting environmental controls on $\mathrm{CH}_{4}$ fluxes in a sub-boreal peatland. Biogeosciences 10, 7971-7981.

Riley, W. J., Subin, Z. M., Lawrence, D. M., Swenson, S. C., Torn, M. S., Meng, L., Mahowald, N. M., Hess, P., 2011. Barriers to predicting changes in global terrestrial methane fluxes: analyses using CLM4Me, a methane biogeochemistry model integrated in CESM. Biogeosciences 8, 1925-1953.

Ringeval, B., Friedlingstein, P., Koven, C., Ciais, P., de Noblet-Ducoudré, N., Decharme, B., Cadule, P., 2011. Climate- $\mathrm{CH}_{4}$ feedback from wetlands 
and its interaction with the climate- $\mathrm{CO}_{2}$ feedback. Biogeosciences 8, 2137 2157.

Rinne, J., Riutta, T., Pihlatie, M., Aurela, M., Haapanala, S., Tuovinen, J.-P., Tuittila, E.-S., Vesala, T., 2007. Annual cycle of methane emission from a boreal fen measured by the eddy covariance technique. Tellus 59B, $449-457$.

Rubin, D. B., 1987. Multiple imputation for nonresponse in surveys. John Wiley, New York, 288p.

Sachs, T., Wille, C., Boike, J., Kutzbach, L., 2008. Environmental controls on ecosystem-scale $\mathrm{CH}_{4}$ emission from polygonal tundra in the Lena River Delta, Siberia. J. Geophys. Res. Biogeosci. 113, G00A03.

Schemske, D. W., Horvitz, C. C., 1988. Plant-animal interactions and fruit production in a neotropical herb: a path analysis. Ecol. 69, 1128-1137.

Schlesinger, W. H., Bernhardt, E. S., 2013. Biogeochemistry: An Analysis of Global Change, third edition Edition. Academic Press, San Diego, 672p.

Sebacher, D. I., Harriss, R. C., Bartlett, K. B., Sebacher, S. M., Grice, S. S., 1986. Atmospheric methane sources: Alaskan tundra bogs, an alpine fen, and a subarctic boreal marsh. Tellus 38B, 1-10.

Segers, R., 1998. Methane production and methane consumption: a review of processes underlying wetland methane fluxes. Biogeochemistry 41, 23-51.

Shulski, M., Wendler, G., 2007. The climate of Alaska. University of Alaska Press, Fairbanks, 216p. 
Sturtevant, C. S., Oechel, W. C., Zona, D., Kim, Y., Emerson, C. E., 2012. Soil moisture control over autumn season methane flux, Arctic Coastal Plain of Alaska. Biogeosciences 9, 1423-1440.

Tagesson, T., Mölder, M., Mastepanov, M., Sigsgaard, C., Tamstorf, M. P., Lund, M., Falk, J. M., Lindroth, A., Christensen, T. R., Ström, L., 2012. Land-atmosphere exchange of methane from soil thawing to soil freezing in a high-Arctic wet tundra ecosystem. Global Change Biol. 18, 1928-1940.

Taylor, J. R., 1997. An introduction to error analysis, second edition Edition. University Science Books, 327p.

Turetsky, M. R., Kotowska, A., Bubier, J., Dise, N. B., Crill, P., Hornibrook, E. R. C., Minkkinen, K., Moore, T. R., Myers-Smith, I. H., Nykänen, H., Olefeldt, D., Rinne, J., Saarnio, S., Shurpali, N., Tuittila, E.-S., Waddington, J. M., White, J. R., Wickland, K. P., Wilmking, M., 2014. A synthesis of methane emissions from 71 northern, temperate, and subtropical wetlands. Global Change Biol. 20, 2183-2197.

Turetsky, M. R., Treat, C. C., Waldrop, M. P., Waddington, J. M., Harden, J. W., McGuire, A. D., 2008. Short-term response of methane fluxes and methanogen activity to water table and soil warming manipulations in an Alaskan peatland. J. Geophys. Res. 113, G00A10.

Ueyama, M., Harazono, Y., Kim, Y., Tanaka, N., 2009. Response of the carbon cycle in sub-arctic black spruce forests to climate change: reduction of a carbon sink related to the sensitivity of heterotrophic respiration. Agric. For. Meteorol. 149, 582-602. 
Ueyama, M., Harazono, Y., Ohtaki, E., Miyata, A., 2006. Controlling factors on the interannual $\mathrm{CO}_{2}$ budget at a subarctic black spruce forest in interior Alaska. Tellus 58B, 491-501.

Ueyama, M., Iwata, H., Harazono, Y., 2014. Autumn warming reduces the $\mathrm{CO}_{2}$ sink of a black spruce forest in interior Alaska based on a nine-year eddy covariance measurement. Global Change Biol. 20, 1161-1173.

Ueyama, M., Kudo, S., Iwama, C., Nagano, H., Kobayashi, H., Harazono, Y., Yoshikawa, K., 2015. Does summer warming reduce black spruce productivity in interior Alaska? J. For. Res. 20, 52-59.

Ullah, S., Frasier, R., Pelletier, L., Moore, T. R., 2009. Greenhouse gas fluxes from boreal forest soils during the snow-free period in Quebec, Canada. Can. J. For. Res. 39, 666-680.

van Hulzen, J. B., Segers, R., van Bodegom, P. M., Leffelaar, P. A., 1999. Temperature effects on soil methane production: an explanation for observed variability. Soil Biol. Biochem. 31, 1919-1929.

van Winden, J. F., Reichart, G.-J., McNamara, N. P., Benthien, A., Damsté, J. S. S., 2012. Temperature-Induced increase in methane release from peat bogs: a mesocosm experiment. PLoS ONE 7, e39614.

Verma, S. B., Ullman, F. G., Billesbach, D., Clement, R. J., Kim, J., Verry, E. S., 1992. Eddy correlation measurements of methane flux in a northern peatland ecosystem. Boundary-Layer Meteorol. 58, 289-304.

Vickers, D., Mahrt, L., 1997. Quality control and flux sampling problems for tower and aircraft data. J. Atmos. Oceanic Technol. 14, 512-526. 
von Fischer, J. C., Hedin, L. O., 2002. Separating methane production and consumption with a field-based isotope pool dilution technique. Global Biogeochem. Cycles 16.

von Fischer, J. C., Rhew, R. C., Ames, G. M., Fosdick, B. K., von Fischer, P. E., 2010. Vegetation height and other controls of spatial variability in methane emissions from the Arctic coastal tundra at Barrow, Alaska. J. Geophys. Res. 115, G00I03.

Whalen, S. C., Reeburgh, W. S., 1988. A methane flux time series for tundra environments. Global Biogeochem. Cycles 2, 399-409.

Whalen, S. C., Reeburgh, W. S., 1990. A methane flux transect along the trans-Alaska pipeline haul road. Tellus 42B, 237-249.

Whalen, S. C., Reeburgh, W. S., 1992. Interannual variations in tundra methane emission: a 4-year time series at fixed sites. Global Biogeochem. Cycles 6, 139-159.

Whalen, S. C., Reeburgh, W. S., Reimers, C. E., 1996. Control of tundra methane emission by microbial oxidation. In: Reynolds, J. F., Tenhunen, J. D. (Eds.), Landscape Function and Disturbance in Arctic Tundra. Ecological Study. Springer-Verlag, pp. 257-274.

Wickland, K. P., Striegl, R. G., Neff, J. C., Sachs, T., 2006. Effects of permafrost melting on $\mathrm{CO}_{2}$ and $\mathrm{CH}_{4}$ exchange of a poorly drained black spruce lowland. J. Geophys. Res. Biogeosci. 111, G02011.

Zhuang, Q., Melillo, J. M., Kicklighter, D. W., Prinn, R. G., McGuire, A. D., 
904 Steudler, P. A., Felzer, B. S., Hu, S., 2004. Methane fluxes between terres905 trial ecosystems and the atmosphere at northern high latitudes during the past century: a retrospective analysis with a process-based biogeochem907 istry model. Global Biogeochem. Cycles 18, GB3010.

Zona, D., Oechel, W. C., Kochendorfer, J., Paw U, K. T., Salyuk, A. N., ${ }_{909}$ Olivas, P. C., Oberbauer, S. F., Lipson, D. A., 2009. Methane fluxes during the initiation of a large-scale water table manipulation experiment in the 911 Alaskan Arctic tundra. Global Biogeochem. Cycles 23, GB2013. 


\section{List of Tables}

Table 1. Details of the observation system and its modification over the three seasons of observation.

Table 2. Summary of environmental conditions during the three seasons of observation (days of year 120-270).

Table 3. Median values for $\mathrm{CH}_{4}$ exchange by wind direction sector. Ranges in parenthesis indicate $95 \%$ confident intervals. Unit is $\mathrm{nmol} \mathrm{m}^{-2} \mathrm{~s}^{-1}$.

Table 4. Correlation coefficients obtained from linear regression analysis between half-monthly average $\mathrm{CH}_{4}$ exchange and environmental variables. $T_{\mathrm{s}}$ indicates soil temperature, while SWC denotes soil water content. Depth of observation is indicated in the suffix. Statistical significance was indicated by asterisks: ${ }^{*}$ for $p<0.10,{ }^{* *}$ for $p<0.05$, and $* * *$ for $p<0.01$.

Table 5. Total snow-free season $\mathrm{CH}_{4}$ exchange and uncertainty during DOY 134-280 for each wind direction sector; 0-120: moderately wet area, 120-240: drier area, and 240-360: wetter area. Unit is $\mathrm{mmol} \mathrm{m}^{-2}$ season $^{-1}$. 


\section{List of Figures}

Figure 1. Approximate topography around the observation tower. Tower is indicated by a yellow pin near the center of the map. Most of the area was vegetated with black spruce, except the area southwest from the tower, across the trail, where white birch dominates. Base map was obtained from Google Earth.

Figure 2. Ratios of cospectra of vertical wind velocity and methane density to those of vertical wind velocity and sonic virtual temperature for (a), July 1 to August 31 in 2011, (b) June 18 to August 23 in 2012, and (c) July 1 to August 31 in 2013. Cospectra were calculated by wavelet transform. Gray dots indicate individual cospectral ratios with black filled circles showing median values for each frequency scale. Solid line indicates a fitted transfer function to median values: (a) $y=1 /\left(1+17.5 x^{1.9}\right)$, (b) $y=1 /\left(1+21.2 x^{2.0}\right)$, and (c) $y=1 /\left(1+2136.2 x^{3.0}\right)$.

Figure 3. Seasonal variation in environmental variables over the observation season. Daily mean or total values were plotted.

Figure 4. Distribution of half-hourly $\mathrm{CH}_{4}$ exchange, according to wind direction. Error bars represent random error calculated using the method by Finkelstein and Sims (2001).

Figure 5. Average diurnal variations in half-hourly $\mathrm{CH}_{4}$ exchange for May-June 2012 (upper panel) and July-August 2012 (lower panel). Data were plotted for wind direction sectors: 0-120 (moderately wet area), 120-240 (drier area), and 240-360 (wetter area). Symbols show median values; error bars show $95 \%$ confidence intervals. Only median values determined from more than 10 records are shown. Symbols are slightly shifted horizontally 
for visibility.

Figure 6. Seasonal variation in median $\mathrm{CH}_{4}$ exchange for drier, moderately wet, and wetter areas over three observation periods. Median values were derived from half-monthly periods. Error bars show $95 \%$ confidence intervals. Only median values determined from more than 10 records are shown. Symbols are slightly shifted horizontally for visibility.

Figure 7. Relationships between median $\mathrm{CH}_{4}$ exchange for the wetter area (240-360 directional sector) and soil temperature at $0.2 \mathrm{~m}$ depth. Median values were derived from half-monthly periods, same as those in Fig. 6. Time progress is indicated by arrows and months indicated near symbols. Error bars show $95 \%$ confidence intervals.

Figure 8. Path diagrams fitted to half-monthly average data for each wind direction sector. $T_{\mathrm{s}, 0.1 \mathrm{~m}}$ indicates soil temperature at $0.1 \mathrm{~m}$ depth; $\mathrm{SWC}_{0.1-0.2 \mathrm{~m}}$ indicates soil water content at $0.1-0.2 \mathrm{~m}$ depth. U represents regression error. Path coefficients are indicated for each path along with $p$ value. 35,51 , and $43 \%$ of variation in $\mathrm{CH}_{4}$ exchange is explained by the model for drier, moderately wet, and wetter areas, respectively.

Figure 9. Calculated random error against $\mathrm{CH}_{4}$ flux for the 2012 season. Gray dots indicate individual 30-min data, with black filled circles showing median values at certain intervals of $\mathrm{CH}_{4}$ flux. Intervals were determined according to number of data. Solid lines represent fitted regression lines. 
Table 1:

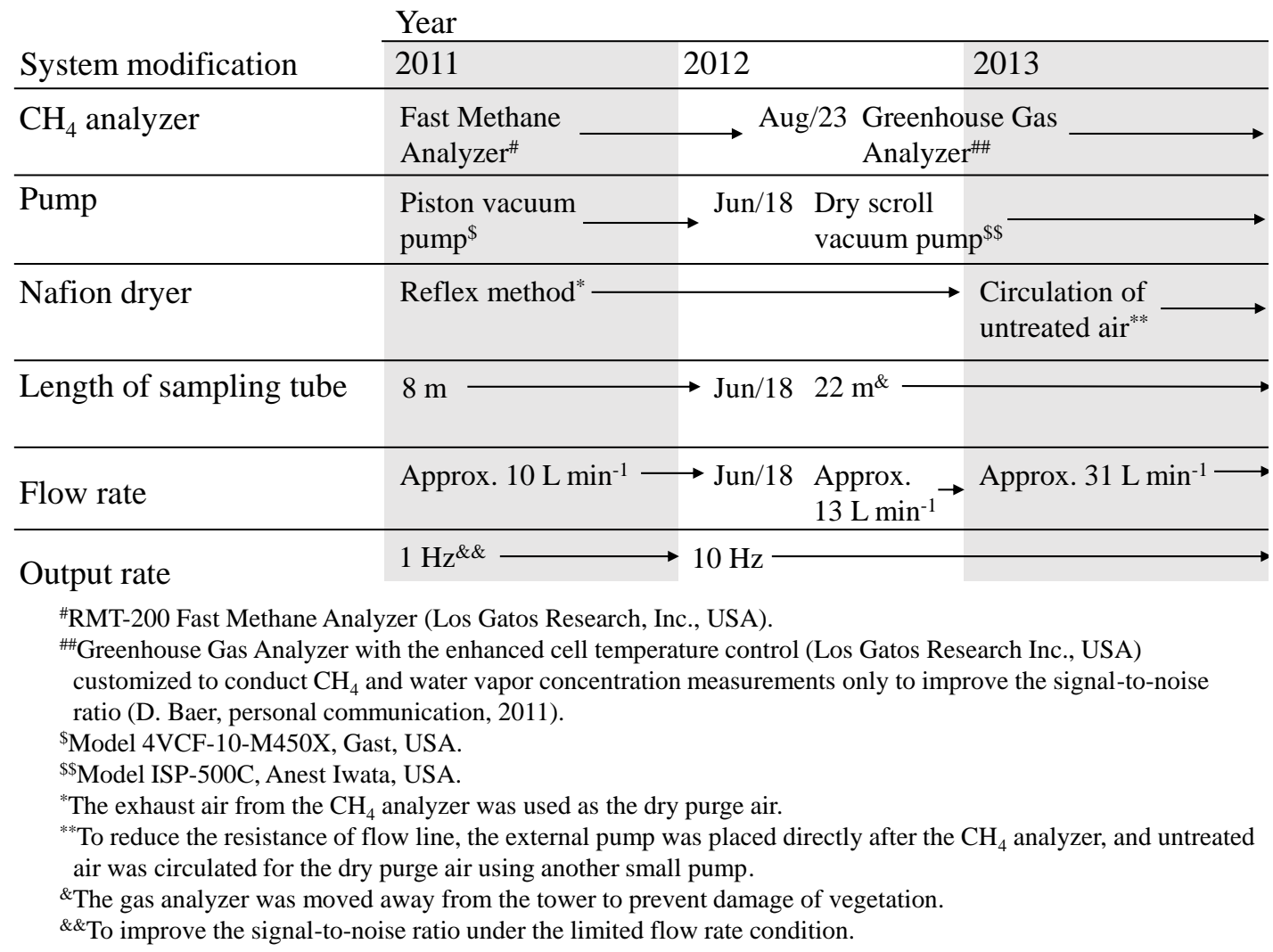


Table 2:

\begin{tabular}{clll}
\hline & \multicolumn{3}{c}{ Year } \\
\cline { 2 - 4 } Environmental conditions & 2011 & 2012 & 2013 \\
\hline Mean air temperature $\left({ }^{\circ} \mathrm{C}\right)$ & 12.1 & 11.5 & 11.2 \\
Range of air temperature $\left({ }^{\circ} \mathrm{C}\right)$ & 0.7 to 22.0 & -4.0 to 20.8 & -3.8 to 25.5 \\
Mean soil temperature $\left({ }^{\circ} \mathrm{C}\right)$ & 3.2 & 3.5 & 3.3 \\
Range of soil temperature $\left({ }^{\circ} \mathrm{C}\right)$ & -0.7 to 7.6 & -0.5 to 8.0 & -7.9 to 9.4 \\
Total solar radiation $\left(\mathrm{GJ} \mathrm{m}{ }^{-2}\right)$ & 2.38 & 2.33 & 2.54 \\
Total rainfall $(\mathrm{mm})$ & 195.1 & 185.3 & 146.1 \\
Maximum thaw depth $(\mathrm{m})$ & 0.40 & 0.36 & 0.33 \\
\hline
\end{tabular}


Table 3:

\begin{tabular}{clll}
\hline & \multicolumn{3}{c}{ Year } \\
\cline { 2 - 4 } Wind direction (degree) & 2011 & 2012 & 2013 \\
\hline $0-60$ & $2.0(1.1-2.7)$ & $1.5(1.1-1.8)$ & $1.3(0.8-1.7)$ \\
$60-120$ & $1.5(1.1-1.9)$ & $1.6(1.4-1.8)$ & $0.9(0.7-1.1)$ \\
$120-180$ & $0.4(0.0-1.0)$ & $0.6(0.5-0.8)$ & $0.5(0.0-0.8)$ \\
$180-240$ & $0.8(0.3-1.5)$ & $0.9(0.7-1.1)$ & $0.7(0.5-1.0)$ \\
$240-300$ & $3.0(2.5-3.3)$ & $2.6(2.4-2.9)$ & $2.6(2.4-3.0)$ \\
$300-360$ & $2.0(1.3-2.7)$ & $2.7(2.4-3.2)$ & $1.8(1.5-2.1)$ \\
\hline
\end{tabular}




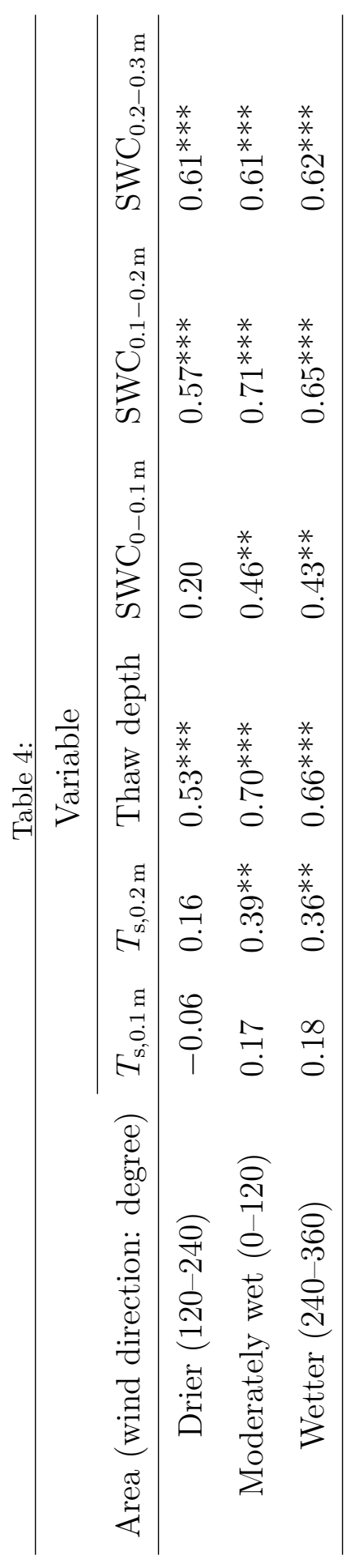


Table 5:

\begin{tabular}{clll}
\hline & \multicolumn{3}{c}{ Year } \\
\cline { 2 - 4 } Area (wind direction: degree) & 2011 & 2012 & 2013 \\
\hline Drier (120-240) & $10.6 \pm 1.6$ & $13.9 \pm 0.8$ & $11.3 \pm 1.2$ \\
Moderately wet (0-120) & $23.2 \pm 1.7$ & $21.9 \pm 1.1$ & $13.7 \pm 1.4$ \\
Wetter (240-360) & $45.0 \pm 1.6$ & $34.6 \pm 1.0$ & $30.3 \pm 1.1$ \\
\hline
\end{tabular}




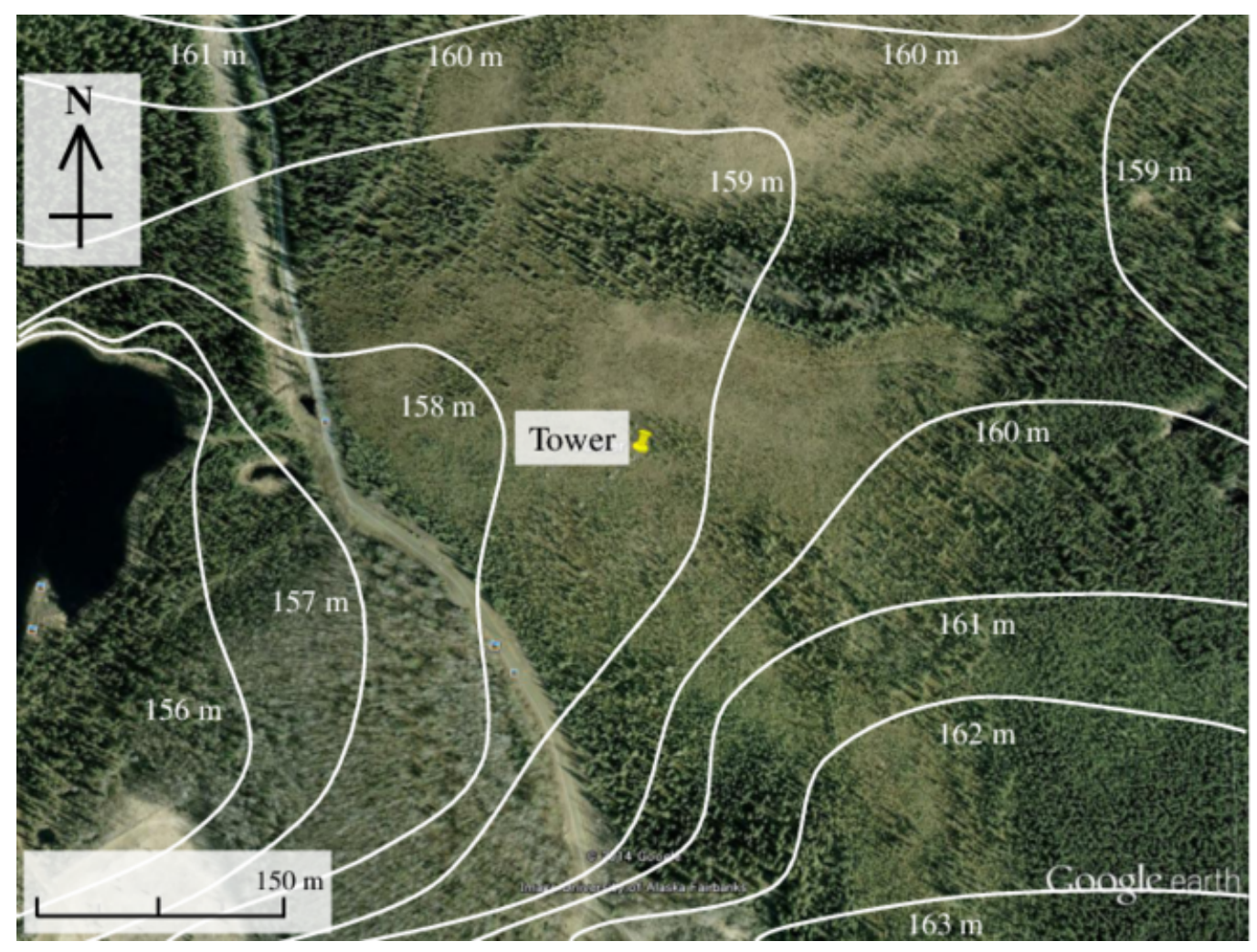

Figure 1: 

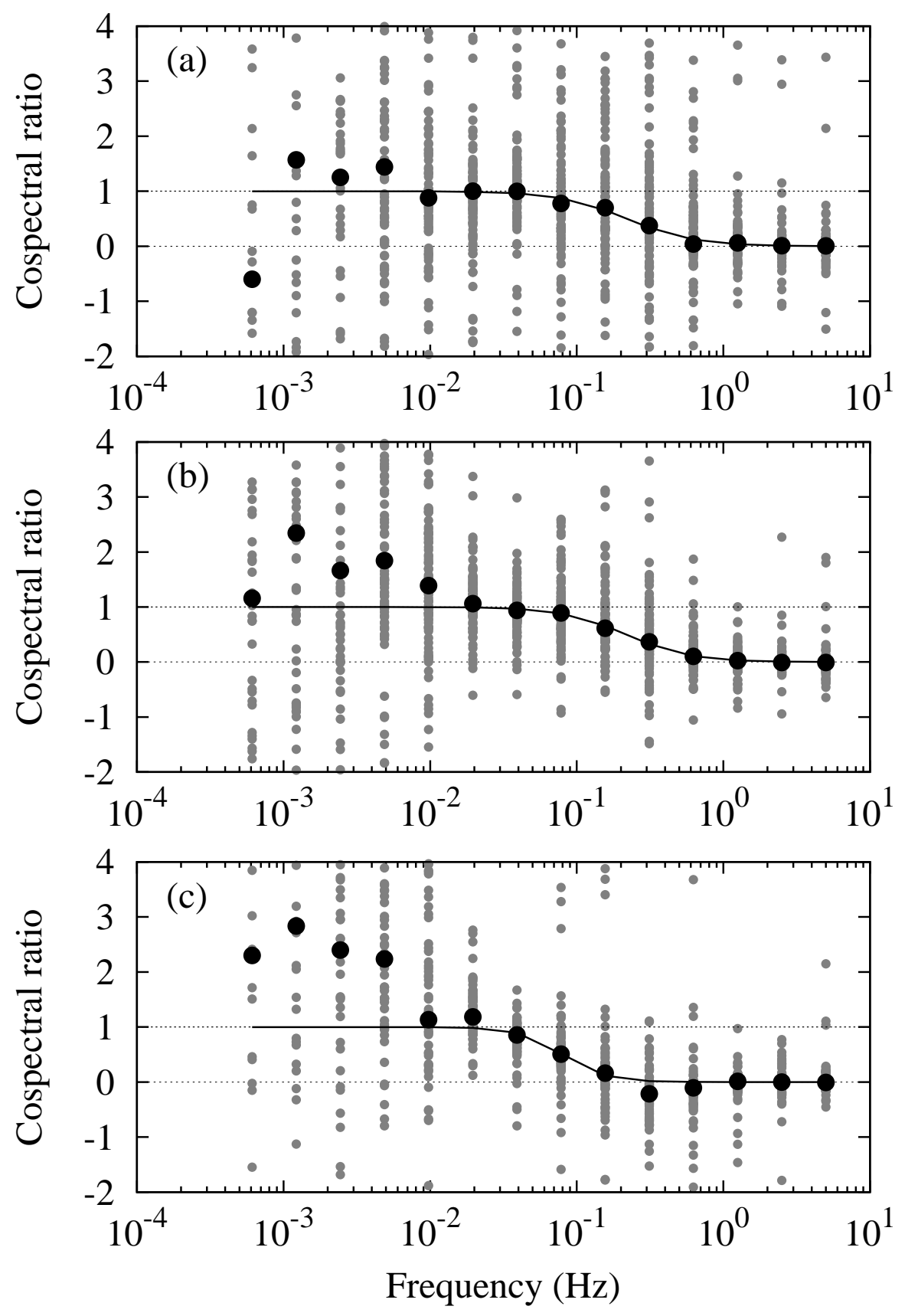

Figure 2: 


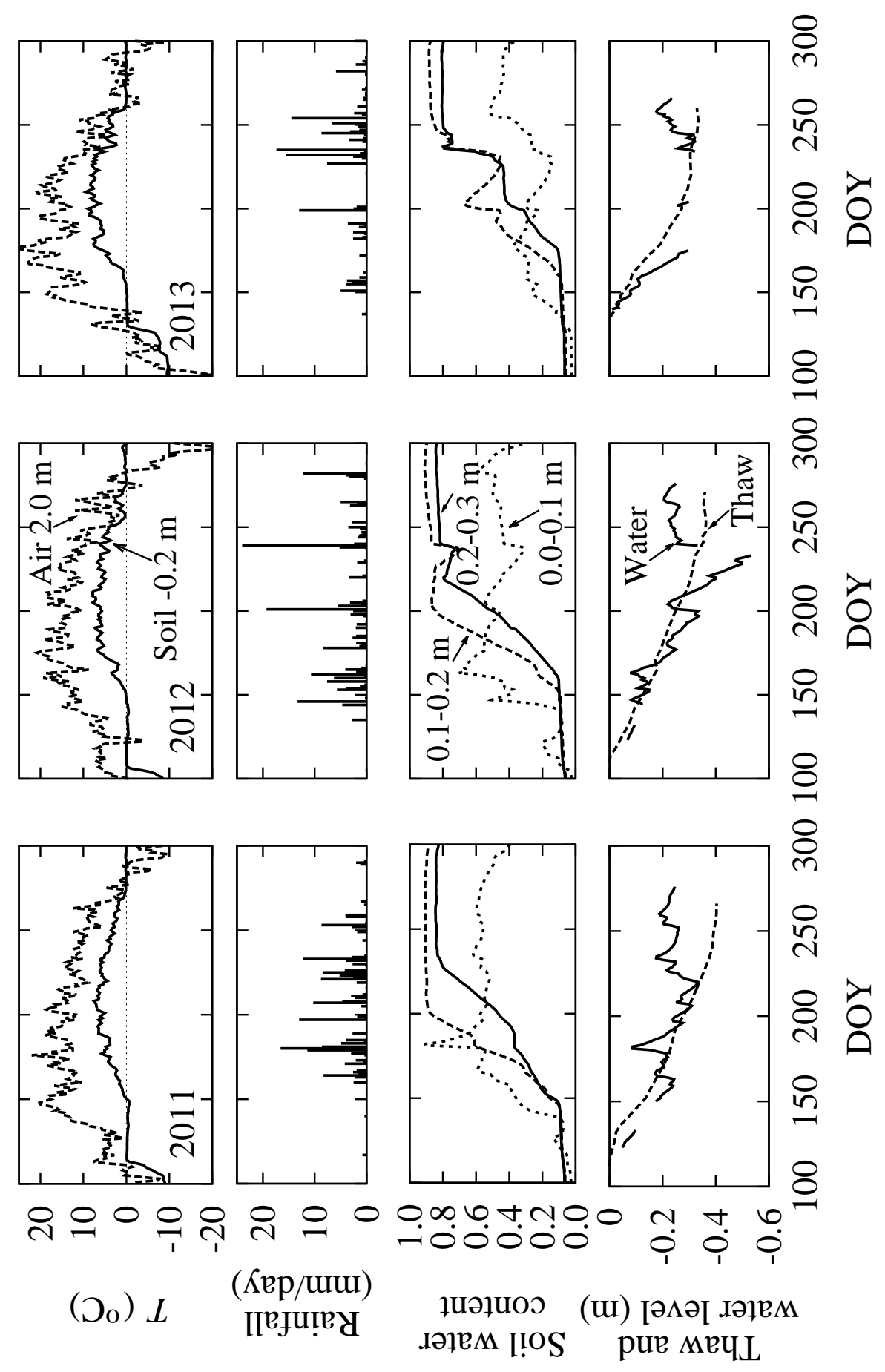

Fig梅( 3: 


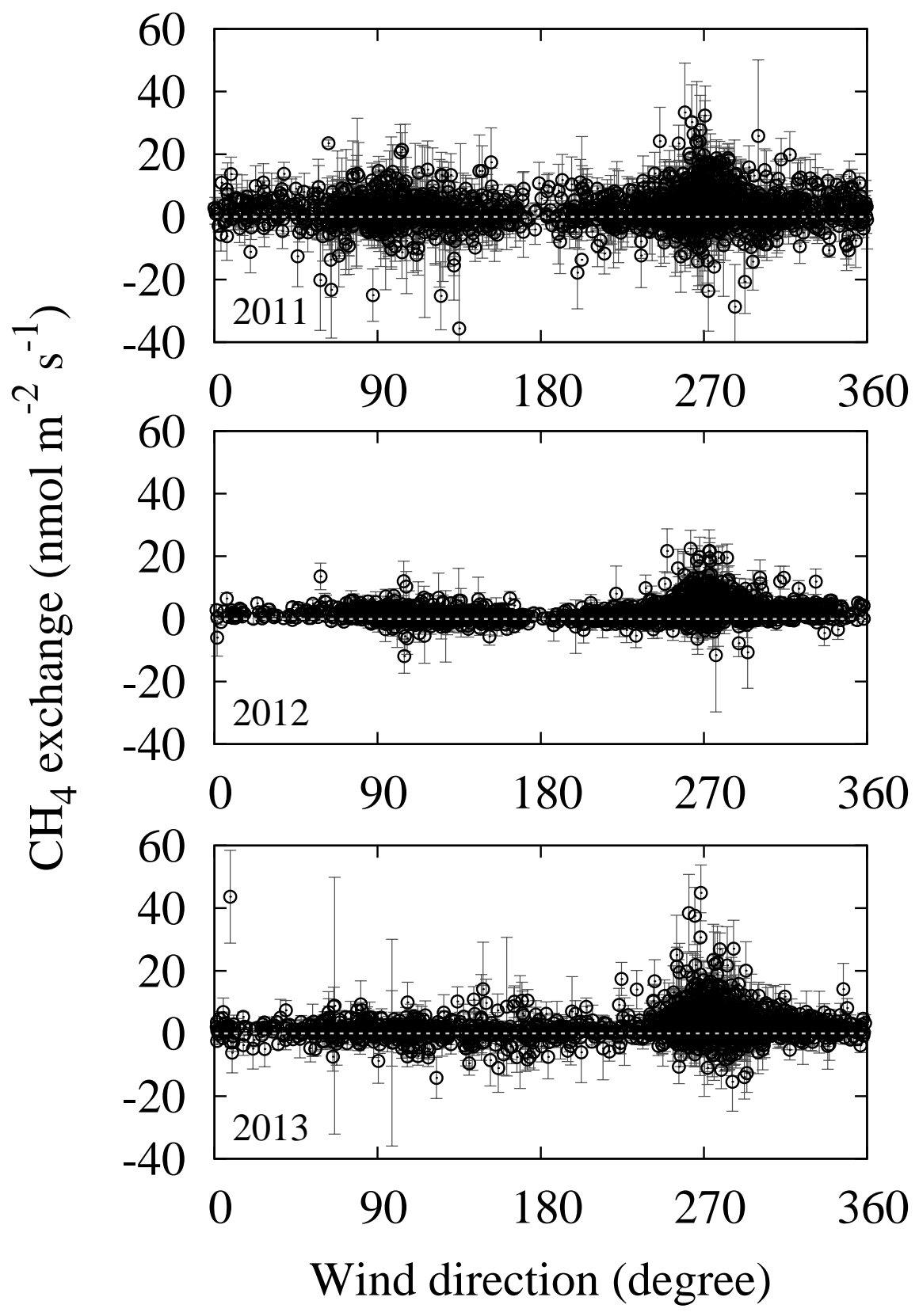

Figure 4: 

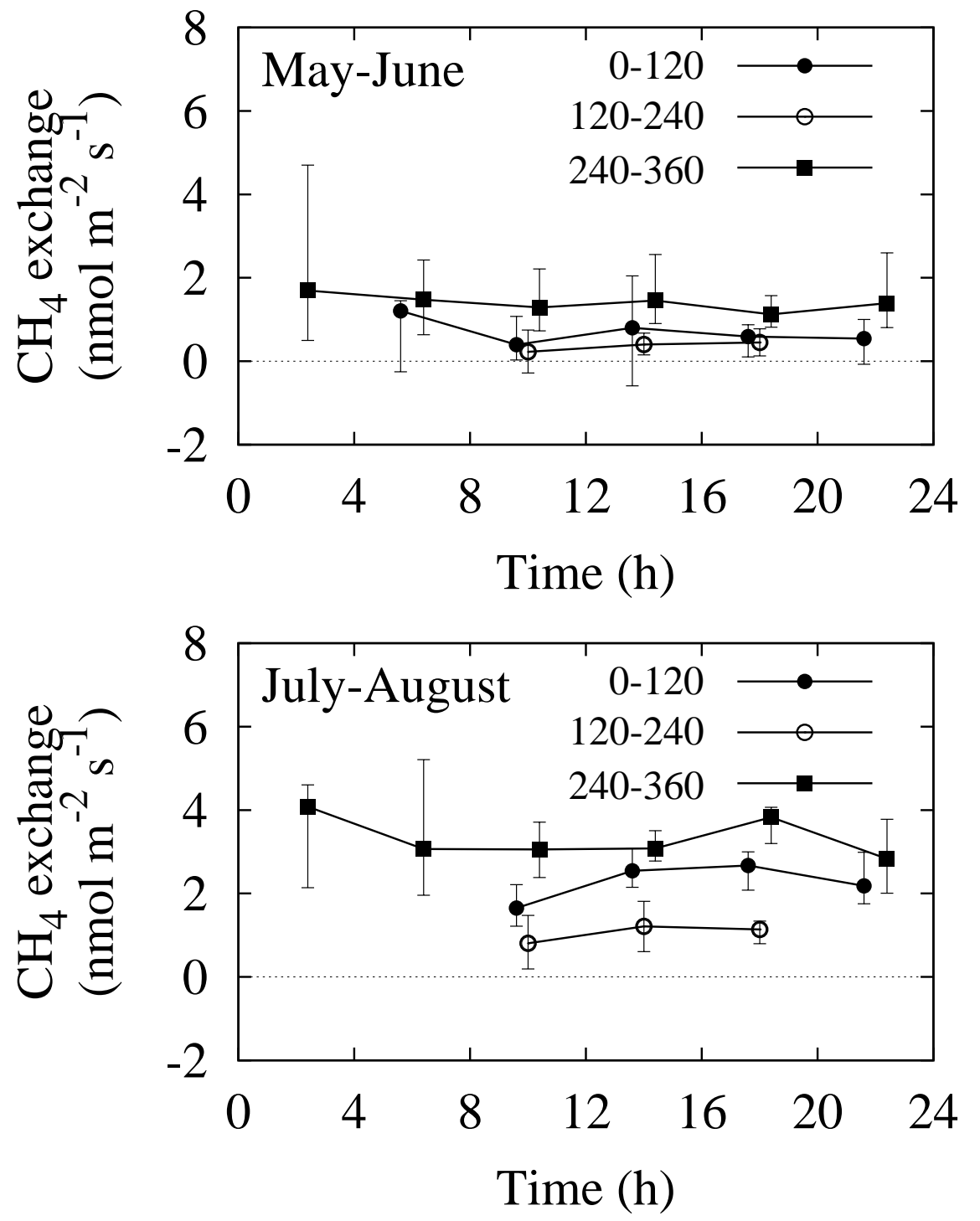

Figure 5: 

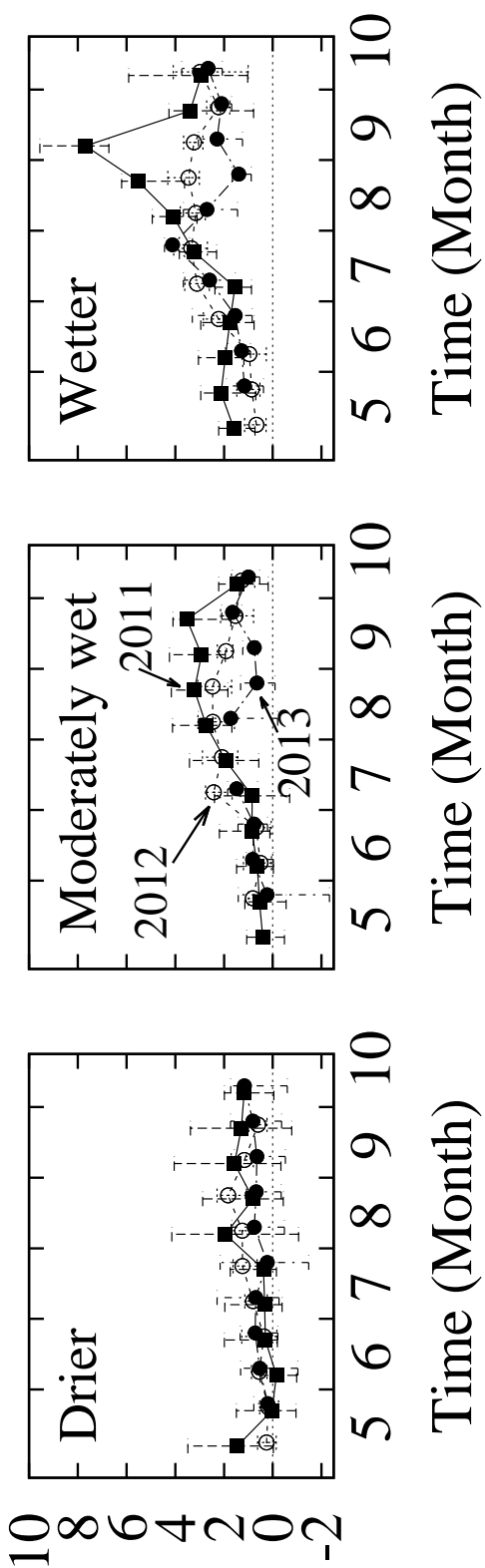

( ${ }^{-}{ }^{2}{ }^{-}$u IOWu) วถันеบวхว ${ }^{\dagger}$ HO

Figure 6: 

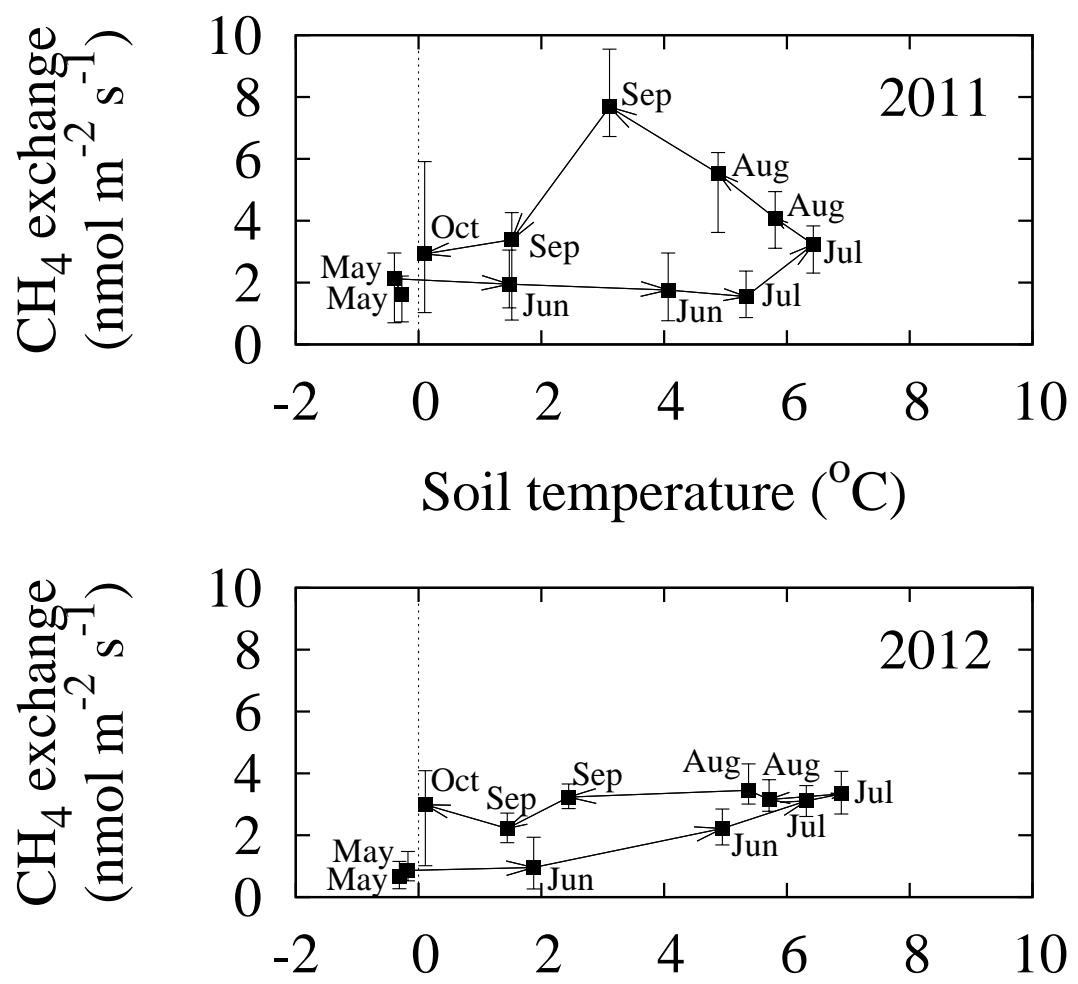

Soil temperature $\left({ }^{\mathrm{O}} \mathrm{C}\right)$

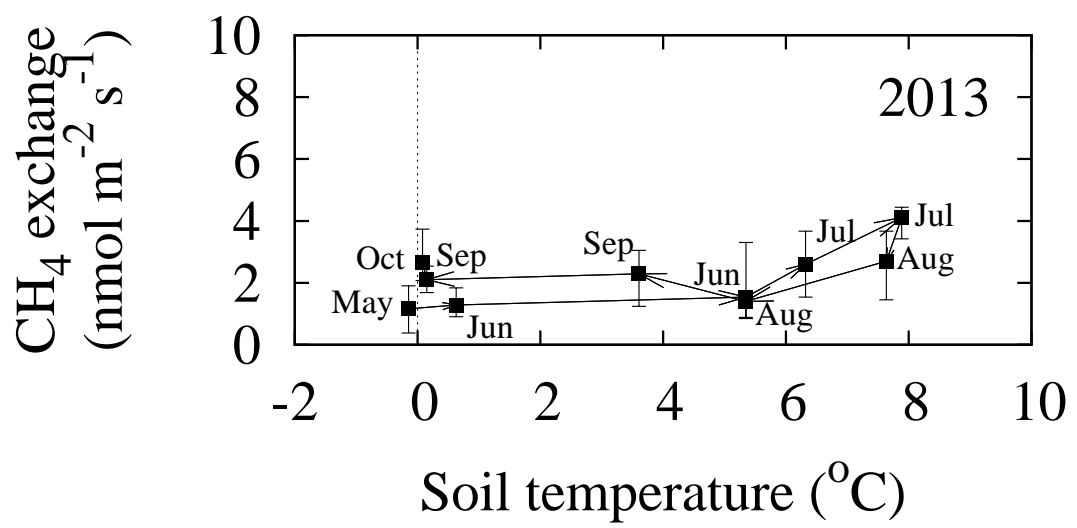

Figure 7: 
Drier (120-240 degree)

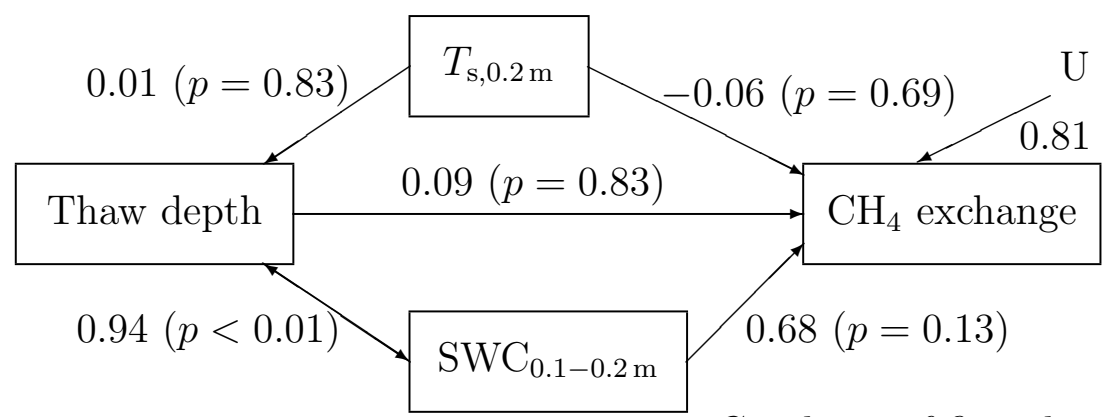

Goodness-of-fit index: 0.94

Moderately wet (0-120 degree)

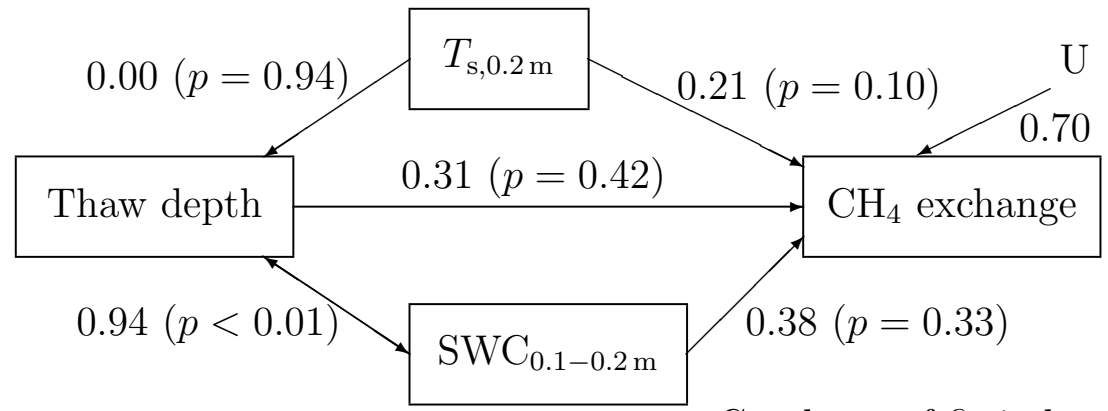

Goodness-of-fit index: 0.96

Wetter (240-360 degree)

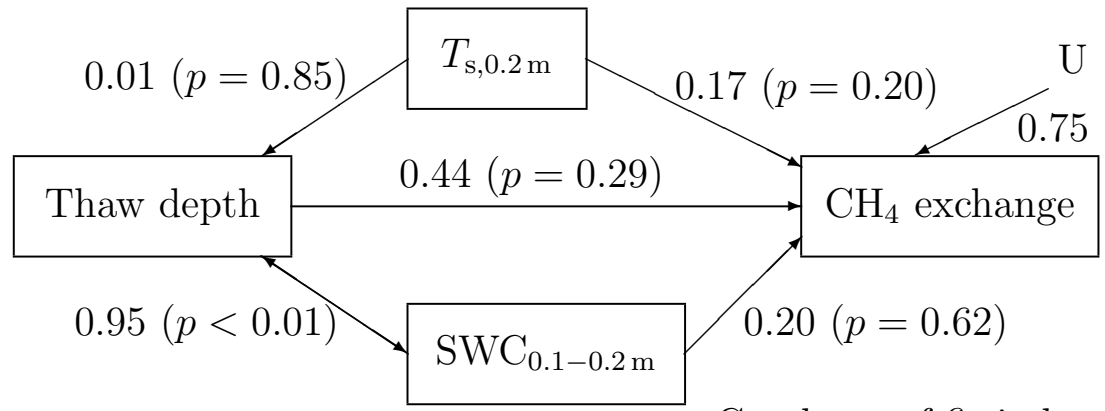

Goodness-of-fit index: 0.95

Figure 8: 


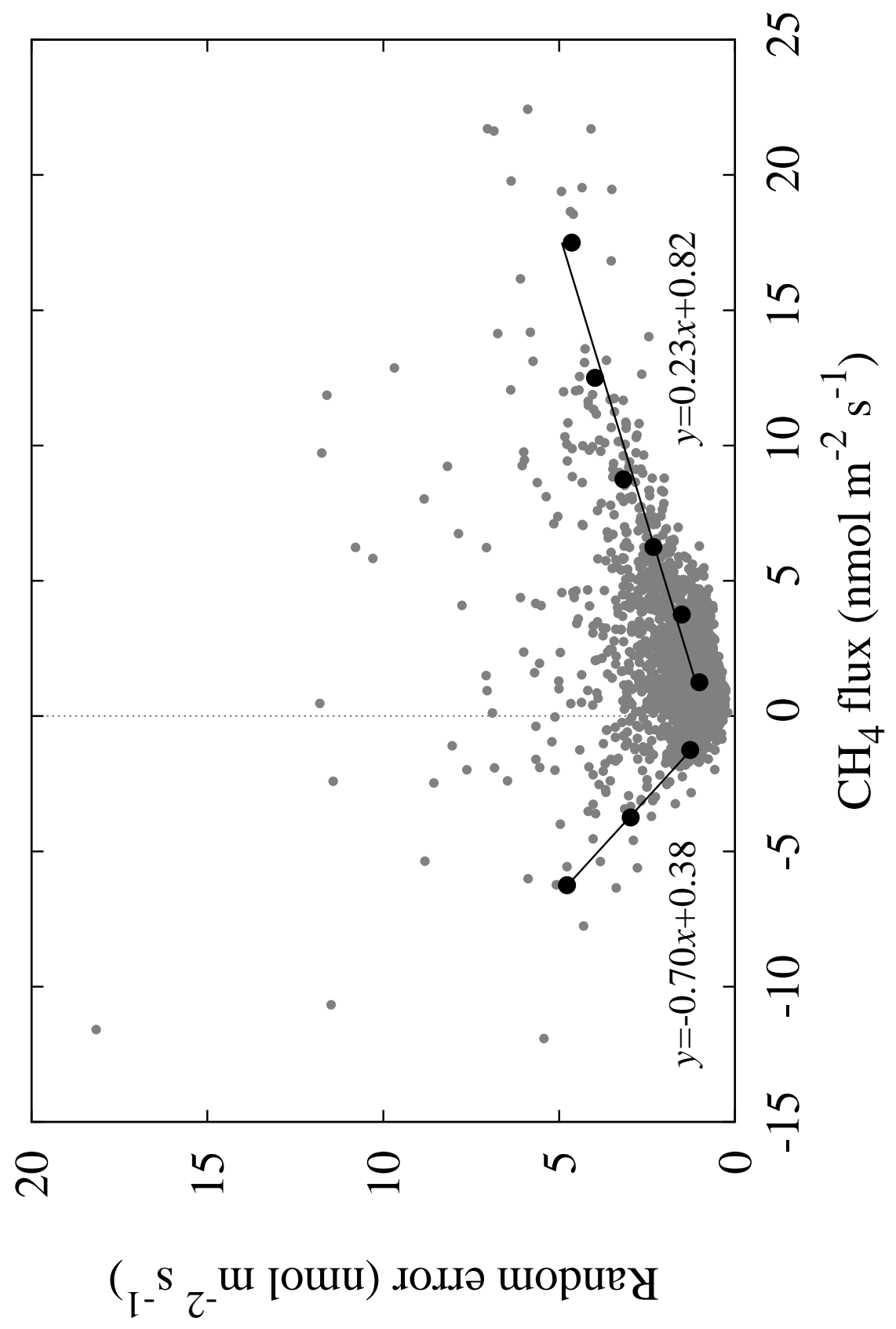

Figure 9: 